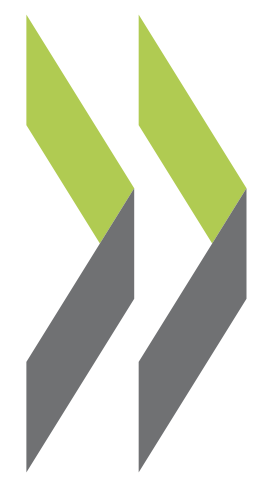

\title{
International Transport Forum Discussion Papers 2014/20
}

\section{Shipping Emissions in Ports}

Olaf Merk

https://dx.doi.org/10.1787/5jrw1 ktc83r1-en 
E International

\section{Shipping Emissions in Ports}

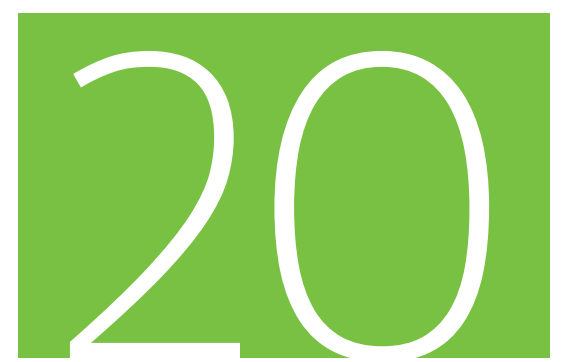

Discussion Paper 2014 20

Olaf Merk

International Transport Forum, Paris, France 


\title{
Shipping Emissions in Ports
}

\author{
Discussion Paper No. 2014-20
}

\section{Olaf MERK}

International Transport Forum, Paris, France

December 2014 


\section{THE INTERNATIONAL TRANSPORT FORUM}

The International Transport Forum at the OECD is an intergovernmental organisation with 54 member countries. It acts as a strategic think-tank, with the objective of helping shape the transport policy agenda on a global level and ensuring that it contributes to economic growth, environmental protection, social inclusion and the preservation of human life and well-being. The International Transport Forum organises an annual summit of Ministers along with leading representatives from industry, civil society and academia.

The International Transport Forum was created under a Declaration issued by the Council of Ministers of the ECMT (European Conference of Ministers of Transport) at its Ministerial Session in May 2006 under the legal authority of the Protocol of the ECMT, signed in Brussels on 17 October 1953, and legal instruments of the OECD.

The Members of the Forum are: Albania, Armenia, Australia, Austria, Azerbaijan, Belarus, Belgium, Bosnia and Herzegovina, Bulgaria, Canada, Chile, People's Republic of China, Croatia, Czech Republic, Denmark, Estonia, Finland, France, Former Yugoslav Republic of Macedonia, Georgia, Germany, Greece, Hungary, Iceland, India, Ireland, Italy, Japan, Korea, Latvia, Liechtenstein, Lithuania, Luxembourg, Malta, Mexico, Republic of Moldova, Montenegro, Netherlands, New Zealand, Norway, Poland, Portugal, Romania, Russian Federation, Serbia, Slovak Republic, Slovenia, Spain, Sweden, Switzerland, Turkey, Ukraine, United Kingdom and United States.

The International Transport Forum's Research Centre gathers statistics and conducts co-operative research programmes addressing all modes of transport. Its findings are widely disseminated and support policymaking in Member countries as well as contributing to the annual summit.

\section{Discussion Papers}

The International Transport Forum's Discussion Paper Series makes economic research, commissioned or carried out at its Research Centre, available to researchers and practitioners. The aim is to contribute to the understanding of the transport sector and to provide inputs to transport policy design.

ITF Discussion Papers should not be reported as representing the official views of the ITF or of its member countries. The opinions expressed and arguments employed are those of the authors.

Discussion Papers describe preliminary results or research in progress by the author(s) and are published to stimulate discussion on a broad range of issues on which the ITF works. Comments on Discussion Papers are welcomed, and may be sent to: International Transport Forum/OECD, 2 rue André-Pascal, 75775 Paris Cedex 16, France.

For further information on the Discussion Papers and other JTRC activities, please email: itf.contact@oecd.org

The Discussion Papers can be downloaded from: www.internationaltransportforum.org/jtrc/DiscussionPapers/jtrcpapers.html

The International Transport Forum's website is at: www.internationaltransportforum.org

This document and any map included herein are without prejudice to the status of or sovereignty over any territory, to the delimitation of international frontiers and boundaries and to the name of any territory, city or area. 


\section{TABLE OF CONTENTS}

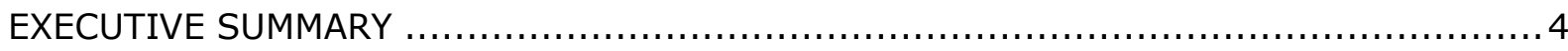

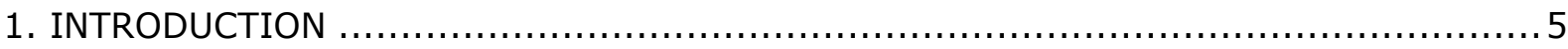

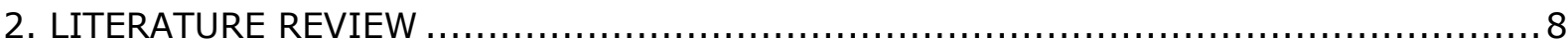

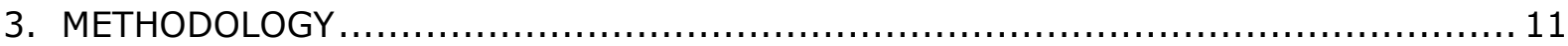

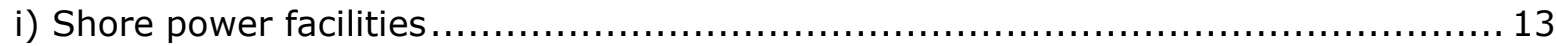

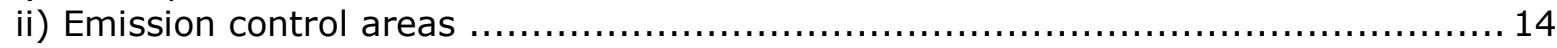

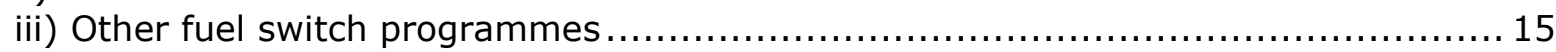

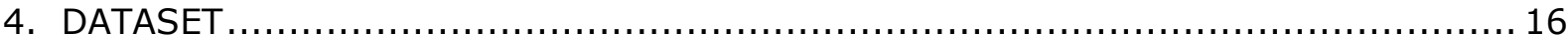

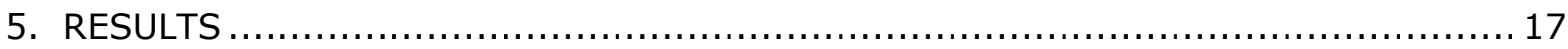

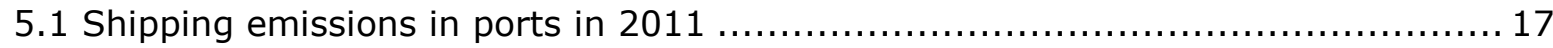

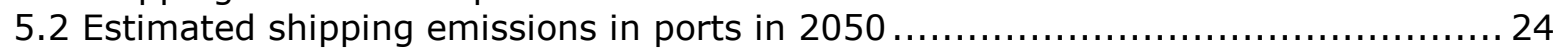

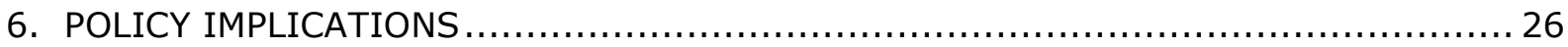

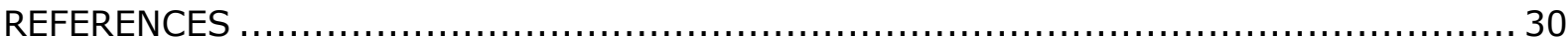

\section{TABLES}

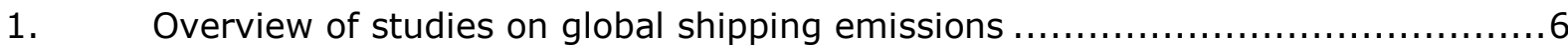

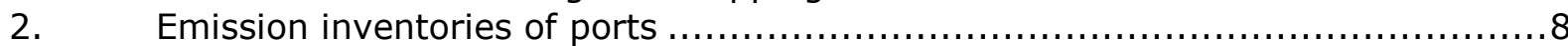

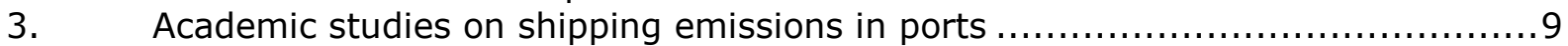

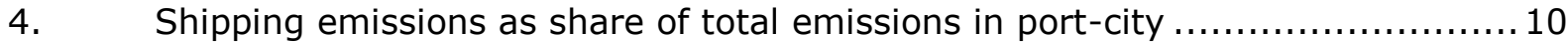

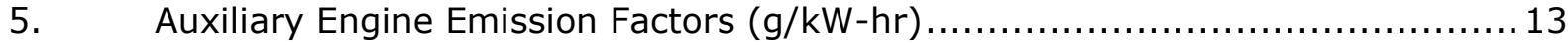

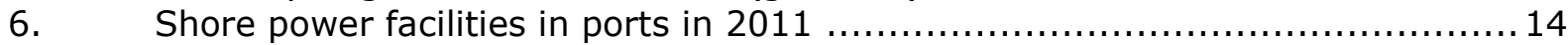

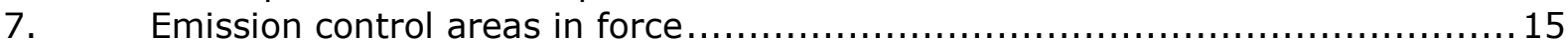

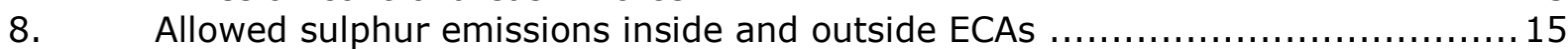

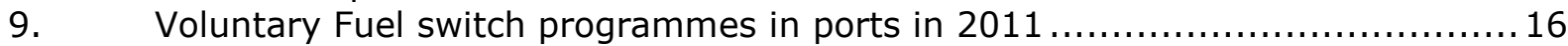

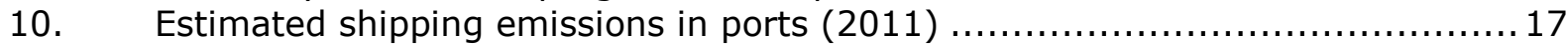

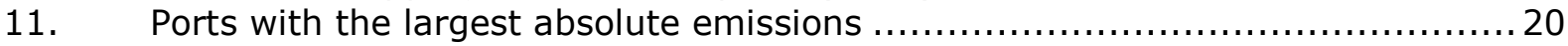

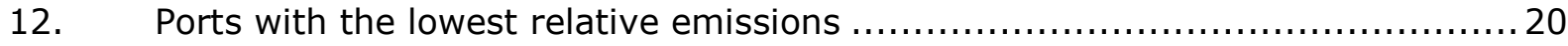

\section{FIGURES}

1. Ship types and their shares in emissions, port calls and port time (2011) ......18

2. Shipping emissions, port calls and port time per continent $(2011) \ldots \ldots \ldots \ldots \ldots 19$

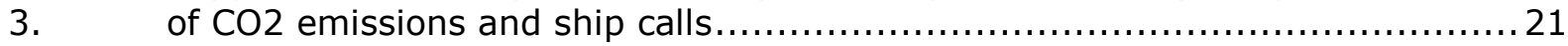

4. Distribution of SOx emissions and ship calls.......................................... 22

5. Size distribution of $\mathrm{CO} 2$ emissions in 100 most active ports .....................22

6. Size distribution of SOx emissions in 100 most active ports .....................23

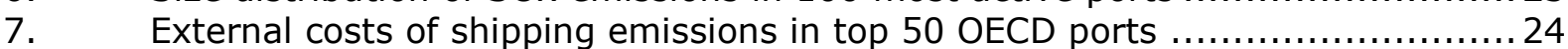

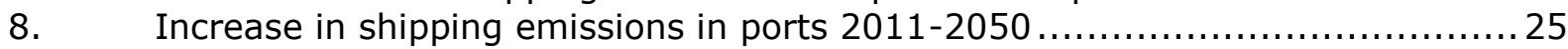

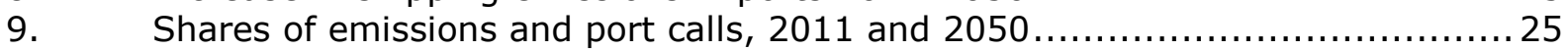




\section{EXECUTIVE SUMMARY}

Shipping emissions in ports are substantial, accounting for 18 million tonnes of $\mathrm{CO}_{2}$ emissions, 0.4 million tonnes of $\mathrm{NO}_{\mathrm{x}}, 0.2$ million of $\mathrm{SO}_{\mathrm{x}}$ and 0.03 million tonnes of $\mathrm{PM}_{10}$ in 2011. Around $85 \%$ of emissions come from containerships and tankers. Containerships have short port stays, but high emissions during these stays.

Most of $\mathrm{CO}_{2}$ emissions in ports from shipping are in Asia and Europe (58\%), but this share is low compared to their share of port calls (70\%). European ports have much less emissions of $\mathrm{SO}_{\mathrm{x}}(5 \%)$ and $\mathrm{PM}(7 \%)$ than their share of port calls $(22 \%)$, which can be explained by the EU regulation to use low sulphur fuels at berth.

The ports with the largest absolute emission levels due to shipping are Singapore, Hong Kong (China), Tianjin (China) and Port Klang (Malaysia). The distribution of shipping emissions in ports is skewed: the ten ports with largest emissions represent $19 \%$ of total $\mathrm{CO}_{2}$ emissions in ports and $22 \%$ of $\mathrm{SO}_{x}$ emissions.

The port with the lowest relative $\mathrm{CO}_{2}$ emissions (emissions per ship call) is Kitakyushu (Japan); the port of Kyllini (Greece) has the lowest $\mathrm{SO}_{\mathrm{x}}$ emissions. Other ports with low relative emissions come from Japan, Greece, UK, US and Sweden.

Shipping emissions have considerable external costs in ports: almost EUR 12 billion per year in the 50 largest ports in the OECD for $\mathrm{NO}_{x}, \mathrm{SO}_{x}$ and $\mathrm{PM}$ emissions, the emissions most directly relevant to local populations. Approximately 230 million people are directly exposed to the emissions in the top 100 world ports in terms of shipping emissions.

Most shipping emissions in ports $\left(\mathrm{CH}_{4}, \mathrm{CO}, \mathrm{CO}_{2}\right.$ and $\left.\mathrm{NO}_{\mathrm{x}}\right)$ are estimated to grow fourfold up to 2050. This would bring $\mathrm{CO}_{2}$-emissions from ships in ports to approximately 70 million tonnes in 2050 and $\mathrm{NO}_{\mathrm{x}}$-emissions up to 1.3 million tonnes. Asia and Africa will see the sharpest increases in emissions, due to strong port traffic growth and limited mitigation measures.

In order to reduce these projected emissions, strong policy responses will be needed. This could take the form of global regulation such as more stringent rules on sulphur content of ship fuel (such as the $0.5 \%$ sulphur cap already agreed by the IMO), or more emission control areas than the four that are currently in place (which would extend the $0.1 \%$ sulphur requirements to more areas). In addition, shipping could be included in market-based mechanisms for climate change mitigation.

A lot could also be gained by policy initiatives of ports themselves. Various ports have developed infrastructure, regulation and incentives that mitigate shipping emissions in ports. These instruments would need wider application in order for ship emissions in ports to be significantly reduced. 


\section{INTRODUCTION}

Shipping could - in one way - be considered a relatively clean transport mode. This is particularly the case if one takes the angle of emissions per tonne-kilometre. Typical ranges of $\mathrm{CO}_{2}$ efficiencies of ships are between 0 and 60 grams per tonne-kilometre, this range is $20-120$ for rail transport and $80-180$ for road transport (IMO 2009). There is considerable variety between vessel types and $\mathrm{CO} 2$ efficiency generally increases with vessel size; e.g. $\mathrm{CO}_{2}$ emissions per tonne-km (in grams per year) for a container feeder ship (with capacity up to 500 TEU) were 31.6, three times higher than the emissions for Post Panamax container ships, with a capacity larger than 4,400 TEU (Psaraftis and Kontovas, 2008). This difference is even larger for dry bulk ships, with a difference of more than a factor 10 between the smallest vessels (up to $5000 \mathrm{dwt}$ ) and capesize vessels (> 120,000 dwt).

At the same time, the air emissions from shipping are considerable. Depending on the methodology, different studies have estimated $\mathrm{CO}_{2}$ emissions from shipping to be around $2-3 \%$ of total global emissions and shares that are much higher for some of the non-GHG emissions: in the range of $5-10 \%$ for $\mathrm{SO}_{\mathrm{x}}$ emissions and $17-31 \%$ for $\mathrm{NO}_{\mathrm{x}}$ emissions (Table 1). A solid body of research exist on shipping emissions in particular parts of the world (e.g. Europe) that confirm the reliability of these shares of shipping emissions (e.g. Cofala et al. 2007).

In comparison with other transport modes, shipping emissions are also substantial. Whereas $\mathrm{CO}_{2}$ emissions of shipping might be approximately a fifth of those of road transport, $\mathrm{NO}_{\mathrm{x}}$ and $\mathrm{PM}$ emissions are almost on a par, and $\mathrm{SO}_{\mathrm{x}}$ emissions of shipping are substantially higher than those of road transport by a factor of 1.6 to 2.7 (ICCT, 2007). According to Eyring et al. (2003) international shipping produces about 9.2 more NOx emissions than aviation, approximately 80 times more $\mathrm{SO}_{\mathrm{x}}$ emissions and around 1200 times more particulate matter than aviation, due to the high sulphur content in ship fuel.

These emissions have increased at a large pace over the last decades and are expected to increase in the future. Eyring et al. (2003) show that main shipping emissions $\left(\mathrm{CO}_{2}\right.$, $\mathrm{SO}_{x}, \mathrm{NO}_{\mathrm{x}}$ and $\mathrm{PM}$ ) grew with a factor of approximately 4 over the period 1950-2001, faster than the increase of the number of ships over that period, which tripled. Shipping emissions are projected to increase over the coming decades. E.g. the IMO assumed in 2014 that shipping-related carbon dioxide emissions would increase with a factor two to three up till 2050 (IMO, 2014).

Although most of these emissions take place at sea, the most directly noticeable part of shipping emissions takes place in port areas and port-cities. It is here that shipping emissions have the most direct health impacts. $\mathrm{NO}_{2}$ and $\mathrm{CO}$-emissions in ports have been linked to bronchitic symptoms, whereas exposure to $\mathrm{SO}_{2}$-emissions is associated with respiratory issues and premature births. Data from the Los Angeles County Health Survey reveal that Long Beach communities in close proximity to the Port of Los Angeles experience higher rates (2.9 percentage points on average) of asthma, coronary heart disease and depression, compared to other communities in Los Angeles (Human Impact Partners, 2010). Additionally, the California Air Resources Board attributed 3700 
premature deaths per year to ports and the shipment of goods (Sharma, 2006). On a global scale, calculations suggest that shipping-related PM emissions are responsible for approximately 60,000 cardiopulmonary and lung cancer deaths annually, with most deaths occurring near coastlines in Europe, East Asia and South Asia (Corbett, 2007).

Table 1. Overview of studies on global shipping emissions

\begin{tabular}{|c|c|c|c|c|}
\hline & $\begin{array}{c}\text { Estimation } \\
\text { (mln tonnes) }\end{array}$ & Year & $\begin{array}{c}\text { Share of total } \\
\text { emissions }\end{array}$ & Source \\
\hline \multirow{8}{*}{$\mathrm{CO}_{2}$} & 949 & 2012 & $2.7 \%$ & IMO 2014 \\
\hline & 1050 & 2007 & $3.3 \%$ & IMO 2009 \\
\hline & 944 & 2007 & - & Psaraftis \& Kontovas 2009 \\
\hline & 695 & 2006 & - & Paxian et al. 2010 \\
\hline & 813 & 2001 & $3 \%$ & Eyring et al. 2005 \\
\hline & 912 & 2001 & $3 \%$ & Corbett \& Koehler 2003 \\
\hline & 501 & 2000 & $2 \%$ & Endresen et al. 2003 \\
\hline & 419 & 1996 & $1.5 \%$ & IMO 2000 \\
\hline \multirow{7}{*}{$\mathrm{SO}_{\mathrm{x}}$} & 10 & 2012 & - & IMO 2014 \\
\hline & 15 & 2007 & - & IMO 2009 \\
\hline & 14 & 2005 & $10 \%$ & ICCT 2007 \\
\hline & 12 & 2001 & $9 \%$ & Eyring et al. 2005 \\
\hline & 13 & 2001 & $9 \%$ & Corbett \& Koehler 2003 \\
\hline & 6.8 & 2000 & $5 \%$ & Endresen et al. 2003 \\
\hline & 16.5 & 2005 & - & Cofala et al. 2007 \\
\hline \multirow{7}{*}{$\mathrm{NO}_{x}$} & 17 & 2012 & - & IMO 2014 \\
\hline & 25 & 2007 & - & IMO 2009 \\
\hline & 22 & 2005 & $27 \%$ & ICCT 2007 \\
\hline & 24.3 & & - & Cofala et al. 2007 \\
\hline & 21.4 & 2001 & $29 \%$ & Eyring et al. 2005 \\
\hline & 22.6 & 2001 & $31 \%$ & Corbett \& Koehler 2003 \\
\hline & 12 & 2000 & $17 \%$ & Endresen et al. 2003 \\
\hline \multirow{6}{*}{$\mathrm{PM}_{10}$} & 1.3 & 2012 & - & IMO 2014 \\
\hline & 1.8 & 2007 & - & IMO 2009 \\
\hline & 1.9 & & - & Cofala et al. 2007 \\
\hline & 1.7 & 2001 & - & Eyring et al. 2005 \\
\hline & 1.6 & 2001 & - & Corbett \& Koehler 2003 \\
\hline & 0.9 & 2000 & - & Endresen et al. 2003 \\
\hline
\end{tabular}

Source: own data collection

However, relatively little is known about ship emissions in ports. The literature review below (section 2) identifies the main studies in this respect, which in most cases are case studies of one port. What is missing is a comprehensive overview of shipping emissions in ports, using a uniform definition and methodology, so that emissions in different ports can be compared with each other. This paper wants to fill this gap, by providing this comprehensive overview of shipping emissions in ports. It considers the following air emissions: $\mathrm{CH}_{4}, \mathrm{CO}, \mathrm{CO}_{2}, \mathrm{NO}_{\mathrm{x}}, \mathrm{PM}_{10}, \mathrm{PM}_{2,5}$ and $\mathrm{SO}_{\mathrm{x}}$. The calculation of shipping emissions in ports makes use of a database of Lloyd's Marine Intelligence Unit on vessel movements in 2011, containing information on turnaround times of ships in ports across the world and ship characteristics, which allows for a bottom-up estimation of ship emissions during port calls. In these calculations, various policy measures implemented in ports to mitigate air emissions have been taken into account, such as the EU regulation to use low sulphur fuel at berth, shore power and various fuel switch programmes. The analysis has been made for different ship types, including 
containerships, bulk carriers, tankers and Roll on/Roll off- (Ro/Ro-) ships, carrying a variety of cargo categories. This calculation has been aggregated into emissions per port and per country in 2011. Projections have been made towards 2050, based on the ITF Freight projection model. These projections have been made per country. 


\section{LITERATURE REVIEW}

There is a limited number of studies on global shipping emissions which contain estimations on the in-port emissions, that is ship emissions in ports. The two examples of these studies are Entec (2002) and Dalsoren et al (2008). The Entec-study (2002) estimates emissions from ships associated with movements between ports in European countries; as they assign ship emissions to $50 \mathrm{~km}$ by $50 \mathrm{~km}$ grid squares the ship-related emissions in port areas are made visible. The paper of Dalsøren et al. (2008) uses an approximation of port time to calculate the in-port shipping emissions, but does not give details on individual ports, except for Singapore. Although these studies certainly have their merits with regards to calculation of ship emissions in ports, they both suffer from relatively inexact data or assumptions on the time that ships spent in a port. The Entec study uses port time data based on a questionnaire survey of ports; and although the Dalsøren et al. paper is more accurate in that it takes actual time in ports, it cannot be very precise because the dataset measures port time in days and not in hours, let alone minutes.

Ports also increasingly measure emissions in port areas themselves via emission inventories (Table 2), but it is not always easy to separate the effects of shipping, port operations, hinterland transport and industrial development on the port site.

Table 2. Emission inventories of ports

\begin{tabular}{|c|c|c|c|}
\hline Port & & Main indicators & Since \\
\hline Los Angeles & & $\begin{array}{l}\text { Port-related GHG emissions (electric wharf cranes, building electricity, building natural } \\
\text { gas, port employee vehicles, expanded GHG inventory) } \\
\text { Diesel particulate matter (DPM), nitrogen oxides }\left(\mathrm{NO}_{\mathrm{x}}\right), \mathrm{SO}_{\mathrm{x}}, \mathrm{CO}_{2 \mathrm{e}} \text { emissions by source } \\
\text { category: Ocean-going vessels (OGV), harbour craft }(\mathrm{HC}) \text {, cargo-handling equipment } \\
\text { (CHE), heavy-duty vehicles (HDV), rail locomotives (RL). } \\
\text { Containerised cargo volume trend } \\
\text { Port DPM, } \mathrm{NO}_{x}, \mathrm{SO}_{x}, \mathrm{CO}_{2 \mathrm{e}} \text { emissions trend }\end{array}$ & 2001 \\
\hline Long Beach & & $\begin{array}{l}\text { Port-related emissions }\left(\mathrm{PM}_{10}, \mathrm{PM}_{2.5}, \mathrm{DPM}, \mathrm{NO}_{\mathrm{x}}, \mathrm{SO}_{\mathrm{x}} \text { carbon monoxide }(\mathrm{CO}), \mathrm{HC}\right) \text { by } \\
\text { category: OGV, } \mathrm{HC}, \mathrm{CHE}, \mathrm{RL}, \mathrm{HDV} \text {. } \\
\text { Port-related } \mathrm{GHG} \text { emissions }\left(\mathrm{CO}_{2 \mathrm{E}}, \mathrm{CO} 2, \mathrm{~N}_{2} \mathrm{O}, \mathrm{CH}_{4}\right) \text { by category: OGV, } \mathrm{HC}, \mathrm{CHE}, \mathrm{RL} \text {, } \\
\text { HDV. }\end{array}$ & 2002 \\
\hline Seattle & & $\begin{array}{l}\text { Total airshed emissions }\left(\mathrm{NO}_{\mathrm{x}}, \mathrm{VOC}, \mathrm{CO}, \mathrm{SO}_{2}, \mathrm{PM}_{10}, \mathrm{PM}_{2.5}, \mathrm{DPM}, \mathrm{CO} 2_{\mathrm{e}}\right) \text { by source } \\
\text { category: OGV, harbour vessels, } \mathrm{RL}, \mathrm{CHE}, \mathrm{HDV} \text {, fleet vehicles }\end{array}$ & \\
\hline $\begin{array}{l}\text { New York } \\
\text { New Jersey }\end{array}$ & - & $\begin{array}{l}\mathrm{GHG} \text { emissions }\left(\mathrm{CO}_{2}, \mathrm{CH}_{4}, \mathrm{~N}_{2} \mathrm{O}, \mathrm{HFCs}, \mathrm{PFCs}, \mathrm{SF}_{6}\right) \text { by the category "Port Commerce" } \\
\text { (commercial marine vessels, } \mathrm{CHE}, \mathrm{RL}, \mathrm{HDV} \text {, buildings, landfill, fleet vehicles) } \\
\text { Port commerce emission per TEU handled } \\
\text { Total Criteria Air Pollutant (CAP) emission }\left(\mathrm{NO}_{x}, \mathrm{NO}_{2}, \mathrm{PM}\right)\end{array}$ & 2006 \\
\hline Oakland & & $\begin{array}{l}\text { Particulate Matter (PM, including diesel), } \mathrm{NO}_{x}, \mathrm{SO}_{2} \text {, Reactive Organic Gas (RO), and } \mathrm{CO} \\
\text { emissions by source category: ships, } \mathrm{HC}, \mathrm{CHE}, \mathrm{RL} \text {, trucks. }\end{array}$ & 2005 \\
\hline Vancouver & & $\begin{array}{l}\text { Common Air Contaminants (CACs): } \mathrm{NO}_{x}, \mathrm{SO}_{x}, \mathrm{CO} \text {, VOCs, } \mathrm{PM}_{10}, \mathrm{PM}_{2.5}, \mathrm{NH}_{3}, \mathrm{GHGs}-\mathrm{CO}_{2} \text {, } \\
\mathrm{CH}_{4}, \mathrm{~N}_{2} \mathrm{O} \text { by source group (administration, } \mathrm{CHE} \text {, on road, rail). }\end{array}$ & 2005 \\
\hline Shanghai & & $\begin{array}{l}\text { Air pollutant emissions }\left(\mathrm{NO}_{x}, \mathrm{SO}_{2}, \mathrm{PM}, \mathrm{VOC}, \mathrm{CO}\right) \text { of ships (ships of international shipping } \\
\text { lines, ships registered at ports and managed by local maritime authorities, ships } \\
\text { travelling along the coast, hotelling, internal rivers). }\end{array}$ & 2006 \\
\hline Gothenburg & & $\begin{array}{l}\text { GHG emissions by: } \\
\text { *Direct emissions: operational vessels, operational vehicles, heating buildings (by fuel } \\
\text { usage), fire equipment } \\
\text { *Energy indirect emissions: electricity usage, direct heating } \\
\text { *Other indirect emissions: business flights gallons per annum, business travel by car }\end{array}$ & 2010 \\
\hline
\end{tabular}




\begin{tabular}{|c|c|c|}
\hline & $\begin{array}{l}\text { gallons per annum, terminals, vessels at the quay/ traffic area, loading of gasoline, } \\
\text { leakage of pipelines, carpool }\end{array}$ & \\
\hline Barcelona & $\begin{array}{l}\text { Air emissions at Darsena Sud and Port Vell: } \mathrm{SO}_{2}, \mathrm{H}_{2} \mathrm{~S}, \mathrm{NO}_{2}, \mathrm{C}_{6} \mathrm{H}_{6}, \mathrm{PM}_{10} \\
\text { Direct } \mathrm{CO}_{2} \text { emissions }\end{array}$ & 2004 \\
\hline Hamburg & $\begin{array}{l}\text { Indirect } \mathrm{CO}_{2} \text { emissions } \\
\mathrm{CO}_{2} \text { emissions by equipment type: straddle carriers, OGVs, container/ rail gantry } \\
\text { cranes, reefer containers, storage cranes }\end{array}$ & 2011 \\
\hline Houston & $\begin{array}{l}\text { Maritime related emissions }\left(\mathrm{NO}_{x}, \mathrm{VOC}, \mathrm{CO}, \mathrm{SO}_{2}, \mathrm{PM}_{10}, \mathrm{PM}_{2.5}, \mathrm{CO}_{2}\right) \text { by source category: } \\
\text { OGV, heavy-duty diesel-fuelled vehicles, } \mathrm{CHE} \mathrm{RL} \text {, harbour vessels }\end{array}$ & 2007 \\
\hline Melbourne & $\begin{array}{l}\mathrm{CO}_{2} \text { emissions by activity: commercial vessels, cargo handling \& Tenants, rail, road } \\
\text { Nitrogen dioxide concentrations, monthly average }\end{array}$ & 2011 \\
\hline Helsinki & $\begin{array}{l}\text { Sulphur dioxide concentrations, monthly average } \\
\text { Vessel waste waters received by Port of Helsinki } \\
\text { Vessel waste waters pumped into sewage systems in Helsinki }\end{array}$ & 2010 \\
\hline
\end{tabular}

Source: Own data collection based on information provided by port authorities.

In addition, there is a considerable amount of case studies of ports and port-cities that calculate the shipping-related emissions on the area. These studies apply a variety of different methodologies and definitions, as can be illustrated by Table 3 below, the outcomes of these studies are difficult to compare with each other (Mueller et al. 2011). Main differences in method are between calculations based on fuel consumption and activity based; the last type of studies takes into account the activity of the ship (such as the hours spent cruising, manoeuvring and hotelling), whereas the first approach is looking at fuel accounts of ships to estimate emissions. The focus of the estimations differs with respect to geographical demarcations (only port area, or also territorial waters), with respect to the ships included (only ocean-going vessels, or also port vessels (such as tugs) and inland river vessels), and with respect to other port activities included, such as other transport modes within the port (port trucks and locomotives) and cargo handling equipment, such as cranes and other equipment.

For this paper, we prepared a database with the main findings of these studies, modified in such a way that it allows for comparison. For this purpose, we took only the shipping emissions in ports into account for ocean going vessels at berth in hotelling and manoeuvring mode. We did not include other vessels, nor equipment, nor port trucks and locomotives.

Table 3. Academic studies on shipping emissions in ports

\begin{tabular}{|c|c|c|c|}
\hline Port & Method & Emissions of: & Source \\
\hline Hong Kong (China) & Activity based (AIS) & OGVs in territorial waters & Yau et al. 2012 \\
\hline Hong Kong (China) & Activity based (AIS) & OGVs in territorial waters & $\mathrm{Ng}$ et al. 2013 \\
\hline Shanghai (China) & Activity based & OGV and inland barges & Yang et al. 2007 \\
\hline Yangshan (China) & Activity-based (AIS) & Vessels in port area & Song 2014 \\
\hline Busan (Korea) & Activity based & Vessels in port area & Song \& Shon 2014 \\
\hline Busan (Korea) & Activity based & Vessels, equipment, port trucks, trains & Shin \& Cheong 2011 \\
\hline Incheon (Korea) & Activity based & Vessels, equipment, port trucks, trains & Han et al. 2011 \\
\hline Kaohsiung (Tapei) & Activity based & Vessels and trucks in port area & Berechman \& Tseng 2012 \\
\hline Kaohsiung (Tapei) & $\begin{array}{l}\text { Cargo capacity, activity } \\
\text { time }\end{array}$ & Merchant vessels & Liu et al. 2014 \\
\hline Klaipeda (Lithuania) & Activity based (LMIU) & Marine ships & Abrutyte et al. 2014 \\
\hline Taranto (Italy) & Air quality measurement & Shipping, industry and urban traffic & Gariazzo et al. 2007 \\
\hline Ravenna (Italy) & Fuel consumption & Vessels in port area & Lucialli et al. 2007 \\
\hline Venice, Piombino (Italy) & Fuel consumption & Marine ships in port area & Trozzi et al. 1996 \\
\hline Venice (Italy) & Air quality measurement & Vessels in port area & Contini et al. 2011 \\
\hline Brindisi (Italy) & & Vessels and port equipment & Donateo et al. 2014 \\
\hline Ambarli (Turkey) & Activity based & Vessels in port area & Deniz \& Kilic 2009 \\
\hline Izmir (Turkey) & Activity based & Vessels in port area & Saraçoglu et al. 2013 \\
\hline Barcelona (Spain) & Activity based & $\begin{array}{l}\text { Vessels, electricity, heating, cargo } \\
\text { handling, vehicles, trucks, waste }\end{array}$ & Villalba\&Gemechu 2011 \\
\hline Piraeus (Greece) & Fuel based \& activity based & Vessels in port area & Tzanattos 2010a \\
\hline
\end{tabular}




\begin{tabular}{|l|l|l|l|}
\hline Victoria, BC (Canada) & Air quality measurement & Cruise ships & Poplawski et al. 2011 \\
\hline Göteborg (Sweden) & Air quality measurement & Ships entering the inner part of port & Isakson et al. 2001 \\
\hline Copenhagen (Denmark) & Air quality measurement & Vessels in ports & Saxe \& Larsen 2004 \\
\hline Mumbai (India) & Activity based & OGVs in port area & Joseph et al. 2009 \\
\hline Aberdeen (UK) & Air quality survey & Ships and trucks in the port area & $\begin{array}{l}\text { Castells Sanabra et al. } \\
2014\end{array}$ \\
\hline 13 main Spanish ports & Activity based & Vessels manoeuvring and hotelling & $\begin{array}{l}\text { Hulskotte \& Denier van } \\
\text { der Gon, 2010 }\end{array}$ \\
\hline Rotterdam (Netherlands) & Fuel consumption & Ships at berth & \\
& & & \\
\hline
\end{tabular}

Source: Own data collection.

The largest part of emissions in ports is generally from shipping activity; this can be concluded from this collection of studies on emissions in ports. Between $70 \%$ to $100 \%$ of emissions in ports in developed countries can be attributed to shipping; trucks and locomotives represent up one fifth, whereas emissions from equipment rarely exceed $15 \%$. The picture is different for ports in developing countries where regulations on truck fuels are less strict and where a larger share of the total emssions in ports is taken up by trucks and locomotives. E.g. in the port of Mumbai, the $\mathrm{NO}_{\mathrm{x}}$ emissions from port trucks are almost $20 \%$ higher than those from ships; and $\mathrm{PM}_{10}$ emissions from trucks are 26 times higher than from ships (Joseph et al. 2009).

Shipping emissions in ports can represent a substantial share of total emissions in the port-city. Much depends on the size of the port, the size of the city and the character of the city, such as industrialisation rate. In some large port-cities, such as Hong Kong and Los Angeles/Long Beach, the share of $\mathrm{SO}_{2}$ emissions can reach half of the total emissions in the city; for $\mathrm{NO}_{\mathrm{x}}$ and particulate matter emission levels that represent up to a fifth of total urban emission are not rare (Table 4).

Table 4. Shipping emissions as share of total emissions in port-city

\begin{tabular}{|l|c|c|c|l|}
\hline \multicolumn{1}{|c|}{ Port } & $\mathbf{S O}_{\mathbf{2}}$ & PM & $\mathbf{N O}_{\mathbf{x}}$ & \multicolumn{1}{c|}{ Source } \\
\hline Hong Kong & $54 \%$ & - & $33 \%$ & Civic Exchange 2009 \\
\hline Shanghai & $7 \%$ & - & $10 \%$ & Hong et al. 2013 \\
\hline Los Angeles/Long Beach & $45 \%$ & - & $9 \%$ & Starcrest 2011 \\
\hline Rotterdam & - & $10-15 \%$ & $13-25 \%$ & Merk 2013 \\
\hline Kaohsiung & $4-10 \%$ & - & - & Liu et al. 2014 \\
\hline Hong Kong & $11 \%$ & $16 \%$ & $17 \%$ & Yau et al. 2012 \\
\hline Taranto & $7 \%$ & - & $3-17 \%$ & Gariazzo et al 2007 \\
\hline Izmir & $10 \%$ & $1 \%$ & $8 \%$ & Saraçoglu et al. 2013 \\
\hline Venice & - & $1-8 \%$ & - & Contini et al. 2010 \\
\hline Brindisi & - & $1 \%$ & $8 \%$ & Di Sabatino et al. 2012 \\
\hline Los Angeles/Long Beach & - & $1-9 \%$ & - & Agrawal et al. 2009 \\
\hline Melila & - & $2-4 \%$ & - & Viana et al. 2009 \\
\hline Algeciras & - & $3-7 \%$ & - & Pandolfi et al. 2011 \\
\hline
\end{tabular}

Source: Own data collection.

The approach in this paper is to provide a comparative overview of shipping emissions in ports. This makes it possible to compare the different emissions in port-cities and go beyond the incidental case studies whose values are difficult to compare to each other. At the same time, it also refines the literature on global shipping emissions in ports by using a more precise dataset on time spent in ports. 


\section{METHODOLOGY}

Several methodologies have been used to estimate emissions from shipping, which can basically be summarized in four models, depending on whether emission evaluation is top-down or bottom up, and whether the geographical characterisation of emissions is top-down or bottom-up (Miola and Ciuffo, 2011):

- In a full top-down approach, total emissions are calculated without considering the vessel characteristics and are after the calculation geographically located and assigned to the different ships. The first studies on ship emissions took this approach and used international marine fuel usage statistics to estimate ship emissions, but results from this approach were later considered to be unreliable.

- In the second approach, a full bottom up approach, air pollutants emitted by a ship in a specific position are calculated; aggregating these estimates over time and over the fleet gives an estimation of the total emissions. This approach can be considered much more reliable, but the data required for such an approach have only recently come available, so for the moment there is a limited amount of studies using this approach. As a result, a considerable amount of studies take approaches that are more hybrid.

- There is a model that is bottom up in the evaluations of total emissions and top down in their geographical characterisation. In this approach, the aggregation of the emissions produced by all the ships gives an estimate of the total emissions; the emissions are then geographically characterised based on assumptions, e.g. ship activities or single geographic cells. A fairly recent approach is to use Automatic Identification System (AIS) data to refine the maritime data.

- The fourth approach is top down in the evaluation of total emissions plus bottom up in the geographic characterisation. In this approach the global activity carried out within a single maritime route or a single geographic cell is evaluated. Emissions from individual cells are aggregated to calculate total emissions and assumptions are made in order to assign total emissions to the different ships.

Our approach here is to use a bottom up-approach with respect to both ship characteristics (horsepower of the engines) and geographical characterisation, that is: the actual time spent in ports (in hours and minutes) by vessels. Following Joseph et al. (2009), the following equation is used to estimate shipping-related emissions at ports:

$\mathrm{E}=\mathrm{P} * \mathrm{LF} * \mathrm{EF} * \mathrm{~T}$

Where:

E emissions in units of pollutant

$\mathrm{P} \quad$ maximum power output of auxiliary engine in $\mathrm{kW}$

LF load factor for auxiliary engines, as a fraction of maximum installed power capacity

EF emission factor (pollutant specific) in mass emitted per work output of the auxiliary engine in manoeuvring and hotelling mode, $\mathrm{g} / \mathrm{kWh}$ and

$\mathrm{T}$ time in manoeuvring and hotelling mode in hours 
The principle behind this equation is to apply emission factors to activity rates, as generally the case when estimating emissions. The activity rate of the individual vessels in our database is estimated using rules of thumb indicated and explained below. Ships use auxiliary power whilst being at berth. The maximum power of auxiliary engines in a vessel is estimated based on auxiliary engine power ratios and an estimation of a vessel's main engine horsepower as a function of dead weight tonnage.

We have made calculations for four different ship categories:

- Container ships (fully cellular containerships).

- Tankers (including crude oil tankers, chemical tankers, combined tankers and product tankers).

- Bulk carriers.

- Roll on/Roll off- (Ro/Ro)-ships.

These ship types include the large majority of commercial vessels used to transport freight. We did not include general cargo ships. We only concentrate on cargo, so did not include passenger ships either.

The auxiliary to main engine power ratio is assumed to be:

- 0.220 for container vessels;

- 0.211 for tankers;

- 0.222 for bulk carriers;

- 0.191 for Ro/Ro-ships.

The estimation of main engine horsepower for different vessels is assumed to follow the equations based on EPA (2000):

- $(0.80 * d w t-/-749.4)$ for container vessels;

- $\quad(0.1083 * d w t+6579)$ for tankers;

- $(0.0985 * \mathrm{dwt}+6726)$ for bulk carriers;

- $(0.288 * \mathrm{dwt}+3046)$ for Ro/Ro-ships.

The total deadweight tonnage of each vessel in the database is known. The load factor for auxiliary engines in manoeuvring and hotelling modes is based on Starcrest (2004) and Starcrest (2007) and considered to be:

- $18 \%$ for container vessels;

- $26 \%$ for tankers;

- $10 \%$ for bulk carriers;

- $26 \%$ for RoRo-ships 
The emission factors for auxiliary engines during transit, manoeuvring and hotelling 1 depend on the type of fuel used (CARB, 2008):

Table 5. Auxiliary Engine Emission Factors (g/kW-hr)

\begin{tabular}{|l|c|c|c|c|c|c|c|}
\hline \multicolumn{1}{|c|}{ Fuel } & $\mathbf{C H}_{\mathbf{4}}$ & $\mathbf{C O}$ & $\mathbf{C O}_{\mathbf{2}}$ & $\mathbf{N O}_{\mathbf{x}}$ & $\mathbf{P M}_{\mathbf{1 0}}$ & $\mathbf{P M}_{\mathbf{2}, \mathbf{5}}$ & $\mathbf{S O}_{\mathbf{x}}$ \\
\hline Marine Distillate (0.1\% S) & 0.09 & 1.10 & 690 & 13.9 & 0.25 & 0.35 & 0.40 \\
\hline Marine Distillate (0.5\% S) & 0.09 & 1.10 & 690 & 13.9 & 0.38 & 0.35 & 2.10 \\
\hline Heavy Fuel Oil & 0.09 & 1.10 & 722 & 14.7 & 1.50 & 1.46 & 11.10 \\
\hline
\end{tabular}

Source: California Air Resources Board (2008)

The values that have been calculated in this way have been corrected for the effects of policies to mitigate air emissions of shipping in ports, in particular: i) shore power facilities in ports; ii) emission control areas (ECAs) and iii) other fuel switch programmes (either mandatory or voluntary).

\section{i) Shore power facilities}

Shore power facilities in ports allow ships to shut off their auxiliary engine and use the power of the grid in the port. Ships that use shore power minimize their emissions - and are considered to be negligible during their stay in the port. We have collected information on the availability of shore power facilities for different ship types in world ports. On the basis of this dataset, we have corrected our calculations for the different ship categories in these ports: containerships, Ro/Ro-ships, tankers and bulk carriers. Whereas shore power facilities are relatively frequently available in container terminals and Ro/Ro-terminals, this is not the case for tankers and bulk carriers. The port of Long Beach is the only port that provides shore power facilities for tankers. ${ }^{2}$

The shore power facilities are not available in all of the container- and Ro/Ro-terminals in the ports below, so the correction of the calculated emission should only apply for the traffic share that these terminals in the total container and Ro/Ro-traffic of the port. Moreover, not all ships are equipped to be connected to shore power facilities, so we have made corrections based on assumptions on how often these facilities are actually used. The estimations of traffic shares of the terminals and of assumed actual use of the shore power facilities are coming from the respective port authorities that we have asked to provide us with this information.

1 The character of the dataset is such that for the vast majority of ports the time in port denotes the arrival at or departure from the port jurisdiction. For the top 10 ports in terms of port calls there is a complexity to size and variation vessels using that port, so the times denote arrival at, or sailing from berth. For these largest ports an estimation has been made for the emissions from manoeuvring, based on a literature study on the shares of hotelling and manoeuvring in the shipping emission in ports. In most studies it is observed that hotelling presents $70-80 \%$ of the ship emissions in the largest world ports such as Hong Kong, Shanghai and Kaohsiung (Song, 2014; Yau et al. 2012; Liu et al. 2014). For the ten ports with the largest number of calls it is thus assumed that manoeuvring emissions represent $25 \%$ of the gross emissions from hotelling (Gross emissions meaning here emissions without taking into account shore power facilities).

2 Shore power facilities for other ship categories such as cruise ships, ferries and river ships are not included in this table 
Table 6. Shore power facilities in ports in $\mathbf{2 0 1 1}$

\begin{tabular}{|l|l|l|c|c|}
\hline \multicolumn{1}{|c|}{ Port } & \multicolumn{1}{|c|}{ Sountry } & & $\begin{array}{c}\text { Traffic share of } \\
\text { terminal(s) with } \\
\text { shore power }\end{array}$ & $\begin{array}{c}\text { Frequency of } \\
\text { use shore power } \\
\text { facilities }\end{array}$ \\
\hline Antwerp & Belgium & Containers & n.a. & $0 \%$ \\
\hline Prince Rupert & Canada & Containers & - & $(25 \%)$ \\
\hline Shanghai & China & Containers & - & $(25 \%)$ \\
\hline Shekou & China & Containers & - & $(25 \%)$ \\
\hline Long Beach & USA & Containers & $100 \%$ & $50 \%$ \\
\hline Los Angeles & USA & Containers & - & $(25 \%)$ \\
\hline Oakland & USA & Containers & $100 \%$ & $38 \%$ \\
\hline Zeebrugge & Belgium & RoRo & $28 \%$ & $45 \%$ \\
\hline Luebeck & Germany & RoRo & $100 \%$ & $11 \%$ \\
\hline Kemi & Finland & RoRo & - & $55 \%$ \\
\hline Osaka & Japan & RoRo & $100 \%$ & $(25 \%)$ \\
\hline Gothenburg & Sweden & RoRo & $34 \%$ & $40 \%$ \\
\hline Trelleborg & Sweden & RoRo & $8 \%$ & $0 \%$ \\
\hline Tacoma & USA & RoRo & - & $100 \%$ \\
\hline Long Beach & RoRo & Tankers & & $0 \%$ \\
\hline
\end{tabular}

Source: own data collection based on information provided by the port authorities

Note: The Port of Long Beach does not track data on shore power visits, but under the shore power regulation, fleets must plug in $50 \%$ of their visits. The estimation of usage of container terminals at the port of Oakland are based on statistics from January-July 2014. The percentages between brackets are assumptions, as the ports in question never responded to our inquiry.

\section{ii) Emission control areas}

The picture is further complicated by emission control areas (ECAs). These ECAs are sea areas in which stricter controls are established to minimize airborne emissions from ships as defined by Annex VI of the 1997 MARPOL Protocol which came into effect in May 2005. ${ }^{3}$ This Annex VI contains provisions for emission and fuel quality requirements regarding $\mathrm{SO}_{\mathrm{x}}, \mathrm{PM}$ and $\mathrm{NO}_{\mathrm{x}}$, a global requirement and more stringent controls in the emission control areas. There are currently four ECAs: one for the Baltic Sea, for the North Sea, the North American ECA covering most of the US and Canadian coast and the US Caribbean ECA, including Puerto Rico and the US Virgin Islands. In 2011, the year of the dataset on which the analysis is based, only the Baltic Sea ECA and the North Sea ECA were in effect (Table 7); the other two ECAs have by now entered into force which will be of relevance for the projections of shipping emissions in ports. The $\mathrm{SO}_{\mathrm{x}}$ and particulate matter emissions allowed inside and outside ECAs are indicated in Table 8. Although there is speculation about new ECA's, we have not included these in our projections. From $1^{\text {st }}$ January 2016 more stringent $\mathrm{NO}_{\mathrm{x}}$ regulations will be in force in the North American and US Caribbean ECAs: all new-built vessels from that date operating in these ECAs should have Tier III engines, which have much lower maximum $\mathrm{NO}_{\mathrm{x}}$ emissions ( $3.4 \mathrm{~g} / \mathrm{kWh}$ at lowest speed). In our long-term projections, we have taken this into account, assuming that the whole fleet in these ECAs will have been renewed by 2050, so that the relevant $\mathrm{NO}_{\mathrm{x}}$ emission factor for these ports in 2050 is $3.4 \mathrm{~g} / \mathrm{kWh}$ in hotelling mode.

3 A more stringent Annex VI was enforced with significantly tightened emission limits 
Table 7. Emission control areas in force

\begin{tabular}{|l|l|c|c|}
\hline Emission control area & Limited compounds & Adopted & In effect from \\
\hline Baltic Sea & $\mathrm{SO}_{x}$ & $26 / 09 / 1997$ & $19 / 05 / 2006$ \\
\hline North Sea & $\mathrm{SO}_{x}$ & $22 / 07 / 2005$ & $22 / 11 / 2007$ \\
\hline North American & $\mathrm{SO}_{x}, \mathrm{NO}_{x}, \mathrm{PM}$ & $26 / 03 / 2010$ & $01 / 08 / 2012$ \\
\hline US Caribbean Sea & $\mathrm{SO}_{x}, \mathrm{NO}_{x}, \mathrm{PM}$ & $26 / 07 / 2011$ & $01 / 01 / 2014$ \\
\hline
\end{tabular}

Source: www.imo.org

Table 8. Allowed sulphur emissions inside and outside ECAs

\begin{tabular}{|l|l|}
\hline Outside an ECA & Inside an ECA \\
\hline $4.50 \%$ prior to $1^{\text {st }}$ January 2012 & $1.50 \%$ prior to $1^{\text {st }}$ July 2010 \\
\hline $3.50 \%$ between $1^{\text {st }}$ January 2012 and 2020 & $1.00 \%$ between $1^{\text {st }}$ July 2010 and $1^{\text {st }}$ January 2015 \\
\hline $0.50 \%$ from $1^{\text {st }}$ January 2020 & $0.10 \%$ from $1^{\text {st }}$ January 2015 \\
\hline
\end{tabular}

Source: www.imo.org

\section{iii) Other fuel switch programmes}

An additional third element to take into account is the existence of other mandatory or voluntary fuel switch programmes. An important regulation in that respect is the EU Sulphur Directive that prescribes that ships at berth in EU ports need to use fuels with a maximum of $0.1 \%$ sulphur content, which is in place since January 2010 . We take this into account in our analysis by applying the emission factors related to Marine Distillate $0.1 \% \mathrm{~S}$ for all EU ports in our analysis, assuming that the regulation is fully applied. Another piece of regulation covers the State of California. Its legislation requires the use of low sulphur fuel within 24 nautical miles of the California coast; the rules applied in 2011 stipulated the use of Marine gas oil (DMA) at or below $1.5 \%$ sulphur, or Marine diesel oil (DMB) at or below $0.5 \%$ sulphur (CARB, 2011). The maximum allowed sulphur content has since been reduced to $0.1 \%$.

Voluntary fuel switch programmes are applied in various ports and provide incentives to shipping lines to use low sulphur fuel (Table 9). These incentives are either in the form of compensations to shipping lines for the additional fuel costs due to their fuel switches, or lower port dues and tariffs. Both the programmes in Seattle and Houston give reimbursements to shipping lines based on the volume of low-sulphur fuel burned during each port call. In contrast, the Green Port Programme in Singapore gives a 15\% reduction of port dues for vessels that switch to clean fuel (or use approved scrubbers or other abatement measures). These programmes usually take the form of collaboration between the port administration and one or more shipping lines. E.g. the programme in Houston is exclusively with the shipping line CMA*CGM, whereas the Fair Winds Charter in Hong Kong was with the main 17 shipping lines calling the port. A brief questionnaire was sent to the relevant port authorities; the answers to this questionnaire were used to identify the extent of coverage of these programmes (the share of ships of total ships that actually used low-sulphur fuel when they were in the port). These data were taken into account when calculating the shipping emissions in these ports. 
Table 9. Voluntary Fuel switch programmes in ports in 2011

\begin{tabular}{|l|l|l|c|c|}
\hline Port & Country & Programme & $\begin{array}{l}\text { Max. } \\
\text { sulphur } \\
\text { level: }\end{array}$ & Coverage \\
\hline Hong Kong & China & Fair Winds Charter & $0.5 \%$ & $19 \%$ \\
\hline Seattle & US & ABC Fuels & $0.5 \%$ & $73 \%{ }^{4}$ \\
\hline Vancouver & Canada & EcoAction Program & $0.5 \%$ & $18 \%{ }^{5}$ \\
\hline Singapore & Singapore & Green Port Program & $1 \%$ & $0.4 \%$ \\
\hline New York/New Jersey & US & OGV Low Sulphur program & $0.2 \%$ & $(10 \%)$ \\
\hline Houston & US & DERA Fuel Switch Program & $0.2 \%$ & $(10 \%)$ \\
\hline
\end{tabular}

Source: own data collection based on information provided by the port authorities. Numbers for Singapore cover 2012. The percentages between brackets are assumptions, as the ports in question never responded to our inquiry.

Other green port policies have not been taken into account, because they do not have an impact on air emissions in the port. E.g. there was no need to correct for the Vessel Reduction Programme operational in the Port of Long Beach; even if reduced speed decreases air emissions within the 20 nautical miles where the programme applies, it is not relevant to the air emissions of ships at berth. There was no need either to correct for differentiated port dues based on schemes such as the environmental ship index (ESI), that scores ships according to their environmental performance. The first reason is that almost all ports that participated in the programme in 2011 were European ports (where the EU Sulphur directorate applied); the second reason is that the share of ships with an ESI certification is marginal in comparison with the global ship fleet.

\section{DATASET}

The data used are vessel movements of ships world-wide, as collected by Lloyd's Maritime Intelligence Unit (LMIU) The dataset includes data per ship, their characteristics, their arrival and departure time in a port, and their next port of call. On the basis of these raw data, we constructed a database with ship turnaround time per ship per port, which can be aggregated in ship turnaround times per port. The main ship categories included in the database are: container ships, Ro/Ro-ships, tankers and bulk carriers. The database covers exclusively ocean-going vessels, so river barges, which make up a significant part of ship calls in some ports, are excluded from this analysis. The dataset has a very high coverage of the world fleet: close to all vessels in the world are covered by the Lloyd's database.

For budgetary reasons we used a database that covers only May 2011. This month is considered to be a representative month by Lloyd's Maritime Intelligence Unit. Our own observations confirm this. We constructed a database with monthly port volumes of a

4 This percentage represents the share of total vessels in 2011 that used distillate fuels with a maximum sulphur content of $0.5 \%$ for all hotelling auxiliary engine operations.

This percentage represents the share of total vessels in 2011 that used distillate fuels with a maximum sulphur content of $0.5 \%$ for all hotelling auxiliary engine operations 
selection of world ports, which shows that the month of May is in most ports and in most years a month that is has neither consistently lower nor higher volumes than the other months.

Of the total port calls of 20771 vessels (larger than $100 \mathrm{gt}$ ) a small number of observations were excluded because of missing arrival and departure data and some observations are excluded because they were considered to be extreme values that would skew the results; these are the vessel calls with a stay in one port of more than 10 days. What resulted was a database with 100693 port calls (in 874 ports), of which 93\% have precise arrival and departure time in hours and minutes.

For a large majority of ship calls, the precise turnaround time in the port is known. In some cases less precise measurements (ship turnaround time in days, not in hours and minutes) was the only available information. For these missing values, it is assumed that the port time for vessels arriving and leaving the same day is 12 hours, leaving the next day is equivalent to 36 hours, with a port stay of two days equivalent to 50 hours etc. This was necessary for some ports with only a very limited set of precise time observations was available, so taking exclusively these and extrapolate these would risk to be inaccurate.

\section{RESULTS}

\subsection{Shipping emissions in ports in 2011}

Shipping emissions in ports are substantial and accounted for 18 million tonnes of $\mathrm{CO}_{2}$ emissions, 0.4 million tonnes of $\mathrm{NO}_{x}$ emissions, 0.2 million of $\mathrm{SO}_{\mathrm{x}}$ emissions and 0.03 million tonnes of $\mathrm{PM}_{10}$-emisions in 2011, as well as various other emissions (Table 1 ). These shipping emissions in ports present on average approximately $2 \%$ of the total shipping emissions, for the different emission types, as calculated in various studies referenced in the Literature Review (section 2). This share is lower than the one found by Dalsøren et al. (2008) who estimated that emissions due to ships' activities around or in ports account for five per cent of total emissions from shipping. This might be explained by the fact that our study does not take shipping emissions from ships other than oceangoing vessels into account, such as inland barges.

Table 10. Estimated shipping emissions in ports (2011)

\begin{tabular}{|l|c|}
\hline & $\begin{array}{c}\text { Shipping emissions in ports } \\
\text { (min tonnes) }\end{array}$ \\
\hline $\mathrm{CO}_{2}$ & 18.3 \\
\hline $\mathrm{NO}_{\mathrm{x}}$ & 0.4 \\
\hline $\mathrm{SO}_{\mathrm{x}}$ & 0.2 \\
\hline $\mathrm{PM}_{10}$ & 0.03 \\
\hline $\mathrm{PM}_{2,5}$ & 0.03 \\
\hline $\mathrm{CO}$ & 0.03 \\
\hline $\mathrm{CH}_{4}$ & 0.002 \\
\hline
\end{tabular}

Source: Author's calculations and elaborations, based on data from Lloyds Marine Intelligence Unit 
Around $85 \%$ of these emissions come from containerships and tankers. This is partly explained by their dominant presence in terms of port calls, around three quarters of all calls. Both containerships and tankers have more emissions than could be expected based on the number of port calls. For tankers this can be explained by their relatively long turnaround time in ports. However, this is not the case for containerships: their time in port is approximately $27 \%$ of the port time of vessels, whereas these represent $40 \%$ of the calls. So containerships have relatively short stays in ports, but have relatively high emissions during these stays. The inverse is the case for bulk carriers: they have long turnaround times, but have relatively fewer emissions during their stays in ports. Also Roll-on/roll-off (Ro/Ro) -ships are relatively clean: representing $8 \%$ of port calls and $5 \%$ of port time, they only represent $2 \%$ of the total shipping emissions in ports (Figure $1)$.

Figure 1. Ship types and their shares in emissions, port calls and port time (2011)

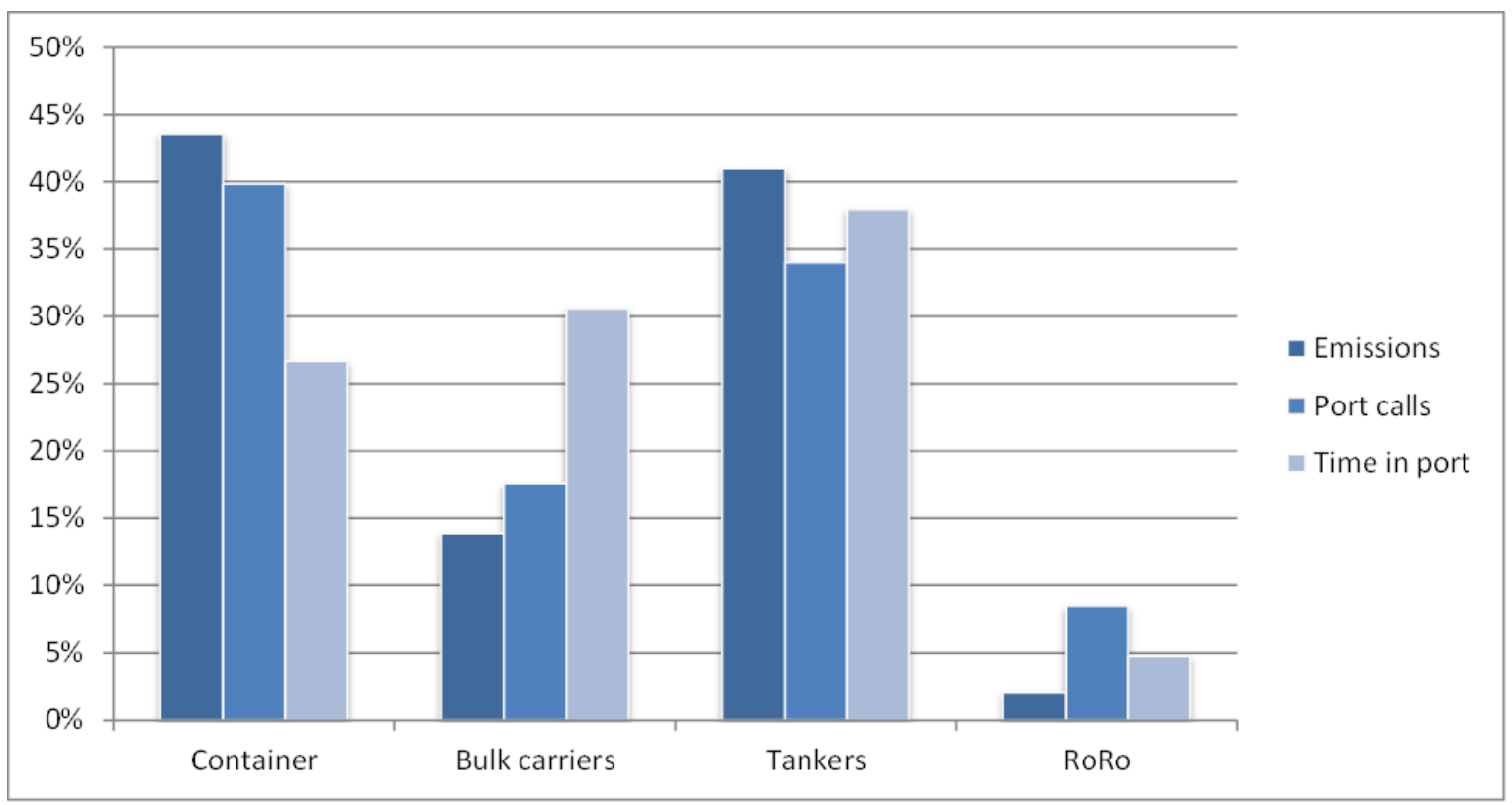

Source: Author's calculations and elaborations, based on data from Lloyds Marine Intelligence Unit

Most of the shipping emissions in ports are concentrated in Asia and Europe, e.g. $58 \%$ of the CO2-emissions. This is logical if one considers that most of world's port activity is taking place there: Asia and Europe represent $70 \%$ of total port calls. Both Asia and Europe have relatively time efficient ports, considering that their calculated time in a port is only $62 \%$, considerably less than their share of port calls. Moreover, European ports have much less emissions of SOx (5\% of world total), PM10 (7\%) and PM2,5 (8\%) than their share of port calls (22\%) would suggest, which can be explained by the EU regulation to use low sulphur fuels at berth. Also its share of CO2-emissions $(19 \%)$ is relatively low, due to port air emissions policies, such as shore power facilities and incentives for fuel switching. Ports with high emissions relative to their port traffic can be found in Africa, the Middle East, Latin America, and - to a slightly lesser extent - in North America (Figure 2). 
Figure 2. Shipping emissions, port calls and port time per continent (2011)

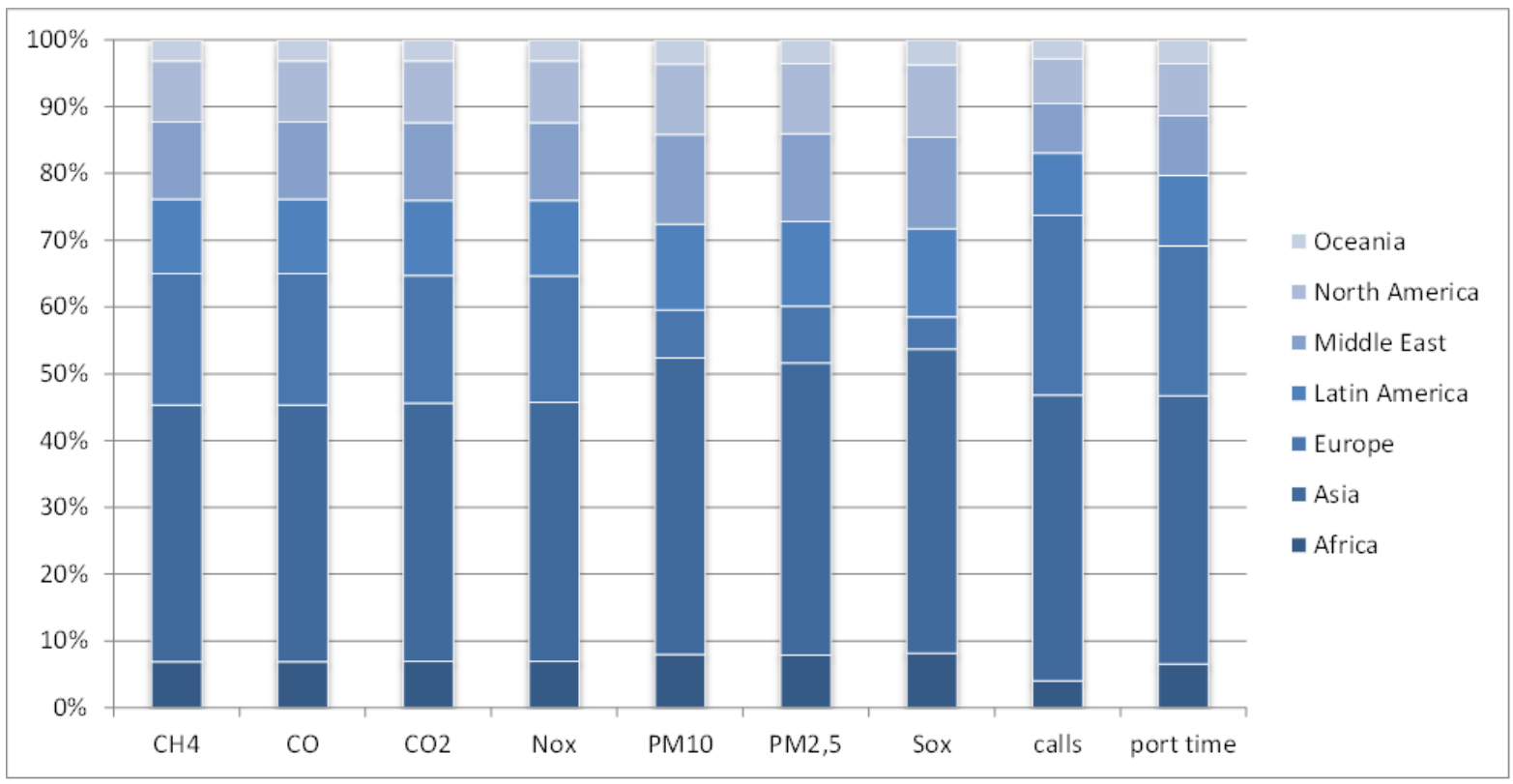

Source: Author's calculations and elaborations, based on data from Lloyds Marine Intelligence Unit

The ports with the largest absolute emission levels due to shipping are Singapore, Hong Kong (China), Tianjin (China) and Port Klang (Malaysia). In all emission categories the port of Singapore shows highest emission levels, for the other ports their position is different with respect to the different emission categories. The top 10 port rankings for $\mathrm{CO} 2$ emissions are similar to those of NOx; and the rankings of SOx and PM are similar as well. This correlation also applies to the whole dataset: there is complete correlation (R2 is 1 ) between CO2 and NOx shipping emissions per ports, as well as for PM and SOx (R2 of 0.9 for the other relationships). The emission levels per port have been compared with the corrected emissions as calculated in the various studies referenced in the literature review (section); depending on the emission types, the results show high to very high correlations6. The list of ports with largest emissions is not very surprising: most of these ports belong to the largest ports in the world with the highest shipping activity. The difference between the rankings with respect to $\mathrm{CO} 2$ emissions and $\mathrm{SOx}$ emissions could be explained by policy, in particular the EU directive on low sulphur fuel.

The ten ports with largest emissions represent almost a fifth of the total shipping emissions in ports: $19 \%$ for $\mathrm{CO} 2$ emissions and $22 \%$ for SOx emissions. This illustrates the highly skewed nature of shipping emissions in ports. In line with this: the 50 ports with largest emissions have $37 \%$ of the $\mathrm{CO} 2$ and $44 \%$ of the total SOx emissions related to shipping. 
Table 11. Ports with the largest absolute emissions

\begin{tabular}{|l|c|l|c|}
\hline $\begin{array}{l}\text { Top 10 ports } \\
\text { emissions) }\end{array}$ & $\begin{array}{l}\text { Share of } \\
\text { total }\end{array}$ & $\begin{array}{l}\text { Top 10 ports } \mathbf{C O}_{\mathbf{x}} \\
\text { emissions) }\end{array}$ & $\begin{array}{l}\text { Share of } \\
\text { total }\end{array}$ \\
\hline 1. Singapore & $5.9 \%$ & 1. Singapore & $6.5 \%$ \\
\hline 2. Hong Kong & $2.2 \%$ & 2. Hong Kong & $2.3 \%$ \\
\hline 3. Rotterdam & $2.0 \%$ & 3. Port Klang & $2.2 \%$ \\
\hline 4. Port Klang & $1.9 \%$ & 4. Tianjin & $2.1 \%$ \\
\hline 5. Tianjin & $1.8 \%$ & 5. Shanghai & $2.0 \%$ \\
\hline 6. Shanghai & $1.7 \%$ & 6. Fujairah & $2.0 \%$ \\
\hline 7. Fujairah & $1.7 \%$ & 7. Busan & $1.7 \%$ \\
\hline 8. Busan & $1.4 \%$ & 8. Kaohsiung & $1.6 \%$ \\
\hline 9. Kaohsiung & $1.4 \%$ & 9. Ulsan & $1.0 \%$ \\
\hline 10. Antwerp & $1.2 \%$ & 10. Beilun & $0.9 \%$ \\
\hline Total Top 10 & $\mathbf{1 9 . 0 \%}$ & Total Top 10 & $\mathbf{2 2 . 3 \%}$ \\
\hline
\end{tabular}

Source: Author's calculations and elaborations, based on data from Lloyds Marine Intelligence Unit

The ports with the lowest relative emissions come from Japan, Greece, UK, US and Sweden. These are the shipping emissions per ship call in each port. The port with the lowest relative $\mathrm{CO} 2$ emissions is Kitakyushu (Japan); the port of Kyllini (Greece) has the lowest SOx emissions. As with the absolute rankings, the rankings with respect to $\mathrm{CO} 2$ and NOx are similar, as well as the ones for PM and SOx. The ranking is dominated by ports specialised in Ro/Ro-traffic, with Ro/Ro-vessels having relatively low emission levels compared to other ship types. The difference between the rankings with respect to $\mathrm{CO} 2$ emissions and SOx emissions could be explained by the EU directive on low sulphur fuel at berth.

Table 12. Ports with the lowest relative emissions

\begin{tabular}{|l|l|l|l|}
\hline $\begin{array}{l}\text { Ports with lowest } \mathbf{C O}_{\mathbf{2}} \\
\text { emissions per ship call }\end{array}$ & Country & $\begin{array}{l}\text { Port with lowest SO } \\
\text { emissions per ship call }\end{array}$ & Country \\
\hline 1. Kitakyushu & Japan & 1. Kyllini & Greece \\
\hline 2. Imabari & Japan & 2. Guernsey & United Kingdom \\
\hline 3. Kyllini & Greece & 3. Sundsvall & Sweden \\
\hline 4. Guernsey & United Kingdom & 4. Troon & United Kingdom \\
\hline 5. Annapolis & USA & 5. Trelleborg & Sweden \\
\hline 6. Grand Cayman & Cayman Islands & 6. Heysham & United Kingdom \\
\hline 7. Sundsvall & Sweden & 7. Marstal & Denmark \\
\hline 8. Troon & United Kingdom & 8. Jersey & United Kingdom \\
\hline 9. Trelleborg & Sweden & 9. Gourock & United Kingdom \\
\hline 10. Heysham & United Kingdom & 10. Naxos & Greece \\
\hline
\end{tabular}

Source: Author's calculations and elaborations, based on data from Lloyds Marine Intelligence Unit

The absolute levels of shipping emissions in ports can to a large extent be explained by port activity: the ports with more ship calls generally have higher levels of shipping emissions. This is particularly the case for $\mathrm{CO} 2$ (Figure 3) and NOx, with a correlation R2 of 0.86 for both emissions. This correlation is lower for SOx emissions (Figure 4); policies aimed at reducing these emissions in the port have to some extent managed to 'decouple' emissions from port activity. This can also be illustrated by the differences in size distribution of the different shipping emissions: whereas $\mathrm{CO} 2$ emissions to some 
extent correspond to the size-rule distribution (Figure 5), this is much less the case for SOx emissions (Figure 6).

Figure 3. Distribution of $\mathrm{CO} 2$ emissions and ship calls

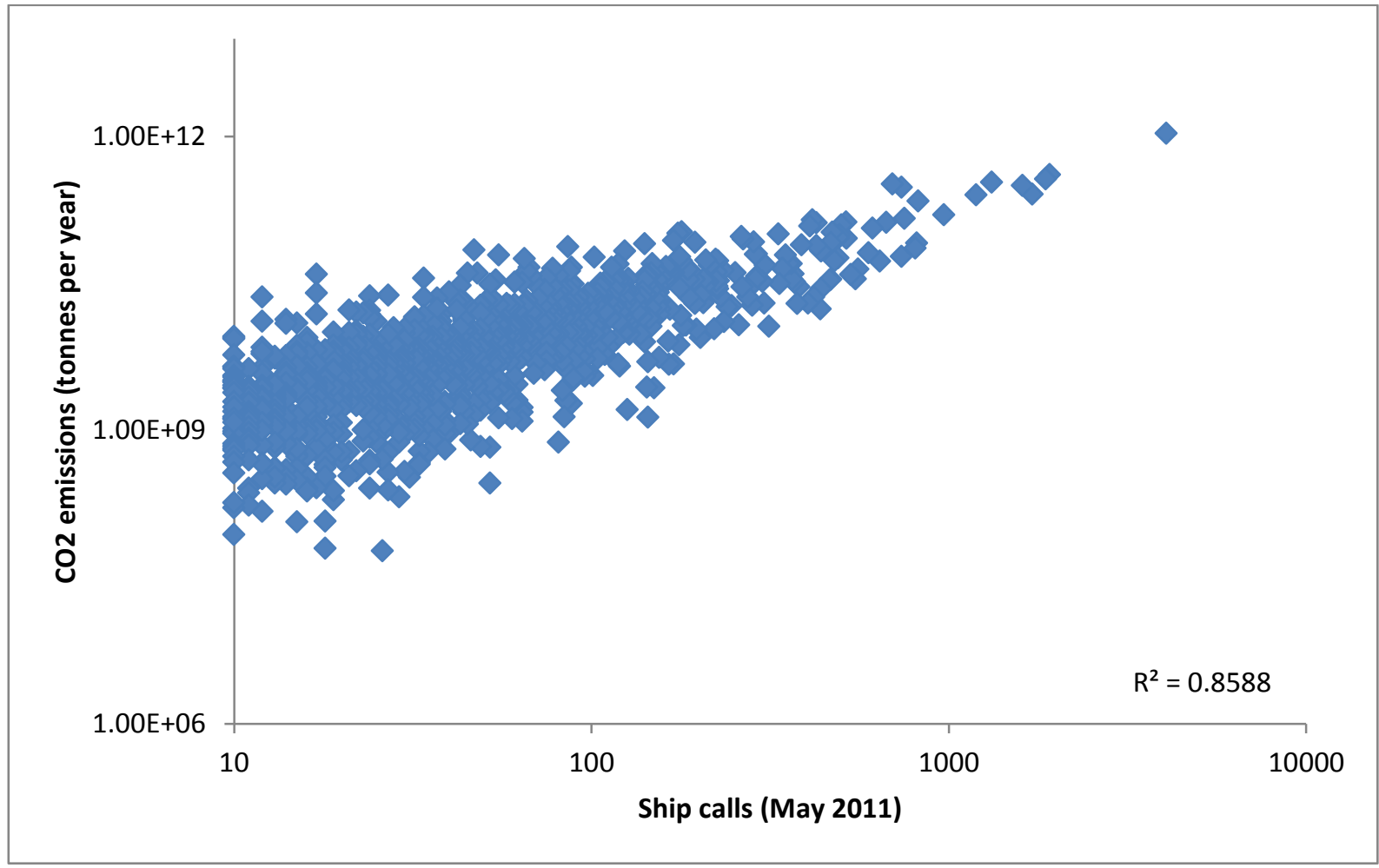

Source: Author's calculations and elaborations, based on data from Lloyds Marine Intelligence Unit Note: The dots in the figure represent ports. 
Figure 4. Distribution of SOx emissions and ship calls

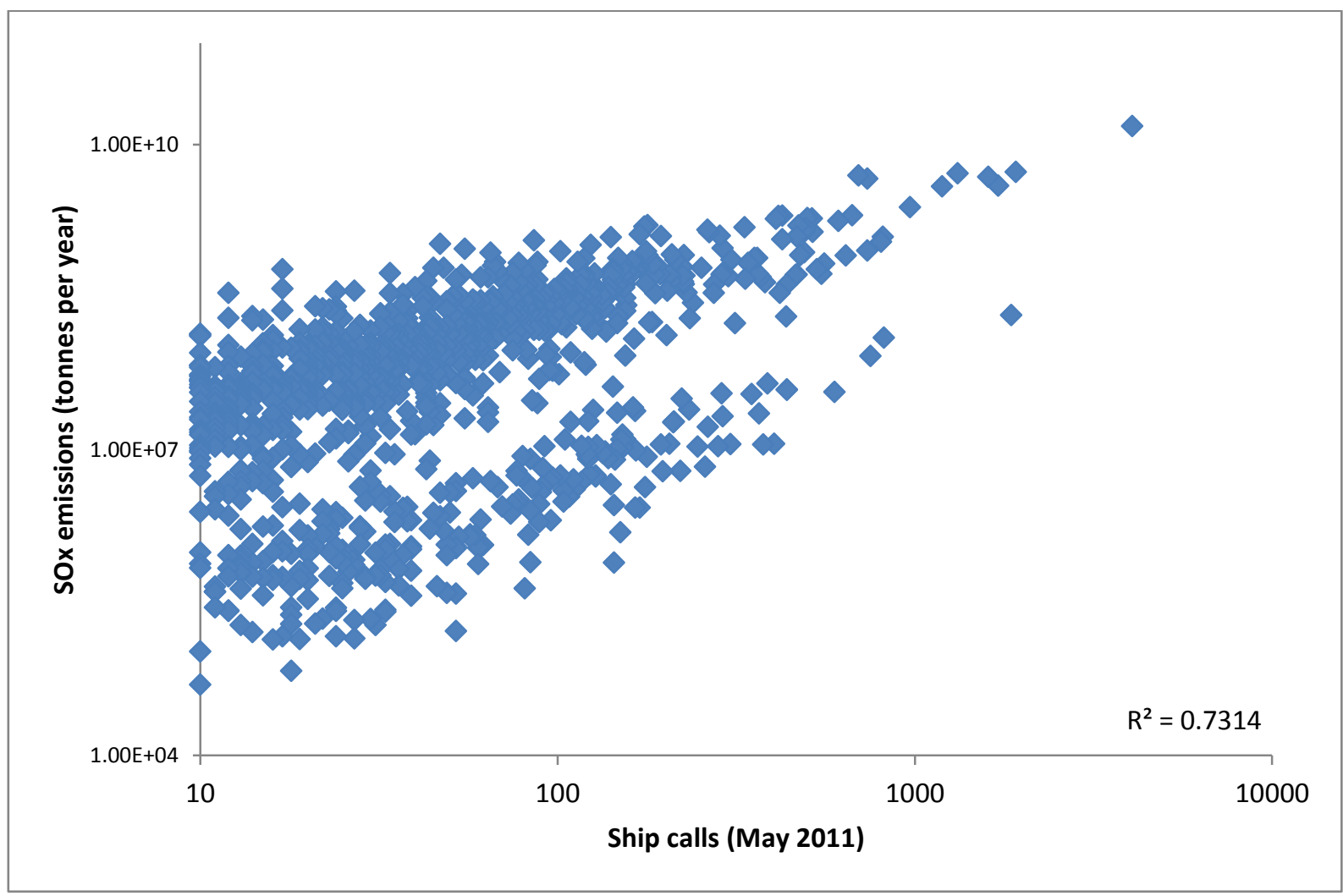

Source: Author's calculations and elaborations, based on data from Lloyds Marine Intelligence Unit Note: The dots in the figure represent ports.

Figure 5. Size distribution of $\mathrm{CO} 2$ emissions in $\mathbf{1 0 0}$ most active ports

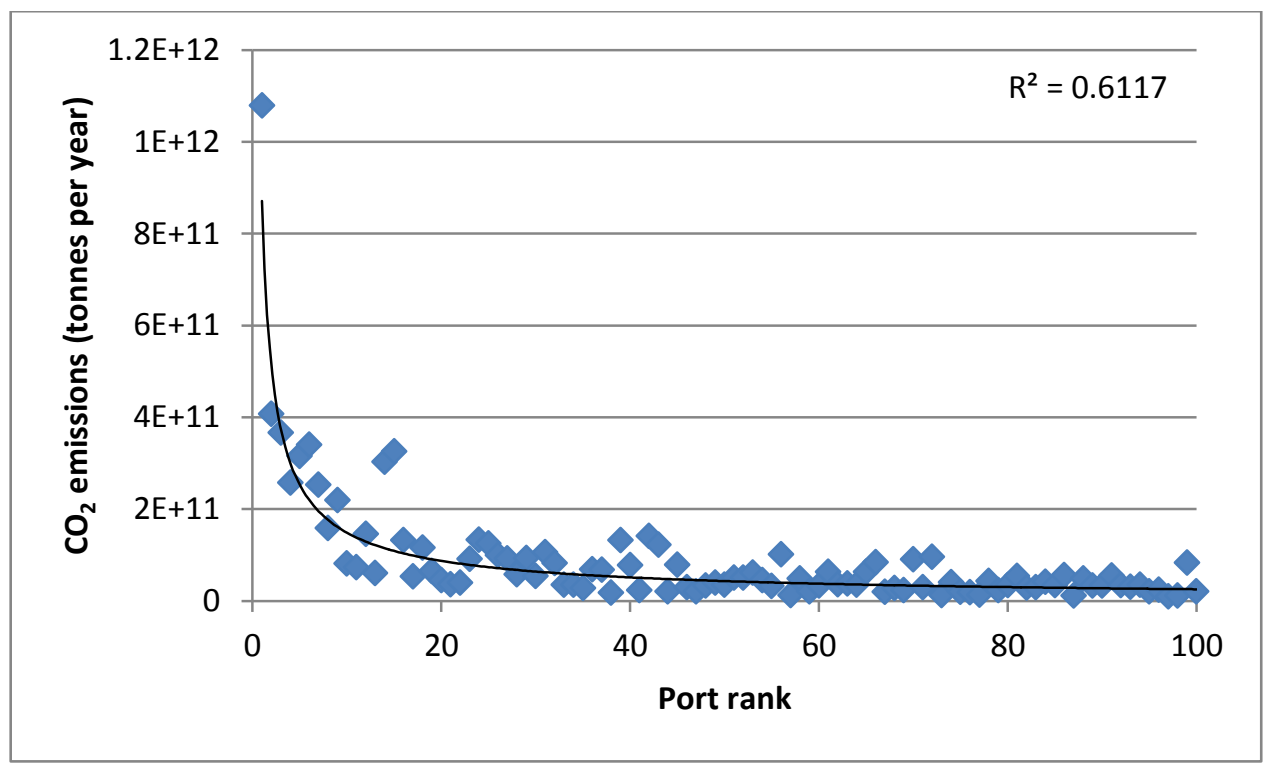

Source: Author's calculations and elaborations, based on data from Lloyds Marine Intelligence Unit 
Figure 6. Size distribution of SOx emissions in $\mathbf{1 0 0}$ most active ports

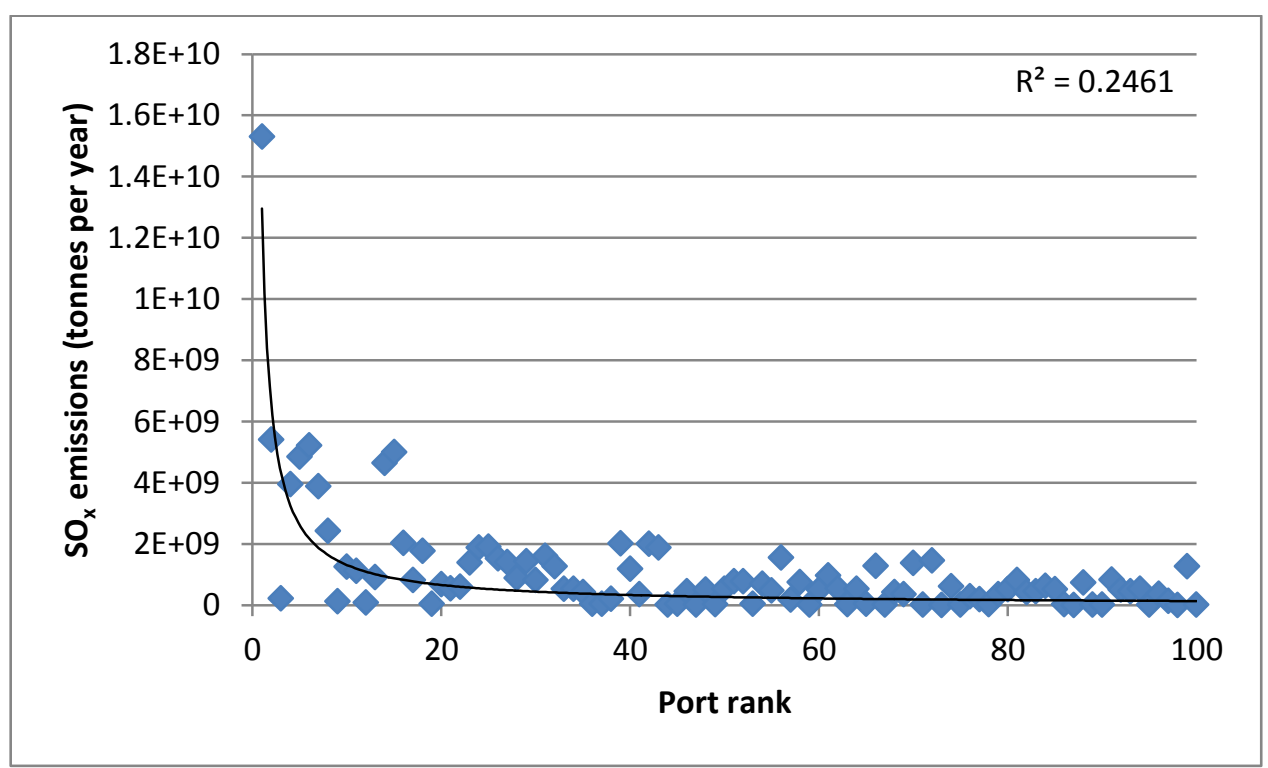

Source: Author's calculations and elaborations, based on data from Lloyds Marine Intelligence Unit

Shipping emissions in ports have large impacts on the population of their cities: approximately 230 million people are directly exposed to the emissions in the top 100 world ports in terms of shipping emissions. Around 40 million people are directly exposed to the ten ports with the largest SOx emissions, which concentrate $22 \%$ of the total shipping-related SOx emissions in ports.

Shipping emissions have considerable external costs in ports: almost EUR 12 billion per year in the 50 largest ports in the OECD for NOx, SOx and PM emissions (Figure 7), based on conservative assumptions. Our calculations follow the approaches in various studies to calculate the external costs of shipping emissions in specific port-cities (McArthur and Osland, 2013; Castells Sanabra et al. 2014). In these studies, like in our calculation, local impact calculation factors are used for a standard city with a population of 100,000 people that are scaled linearly to the respective populations, in our case to the cities or towns with the 50 largest OECD ports. The impact calculation factors used are EUR 33,000 of external costs per ton of PM2,5 emitted, EUR 6,000 for SO2 and EUR 4,200 for NOx, based on Holland and Watkiss (2002). Our calculations are conservative, because these calculation factors are on the lower bound of the factors applied in other studies, such as Holland et al. 2005.7 
Figure 7. External costs of shipping emissions in top 50 OECD ports

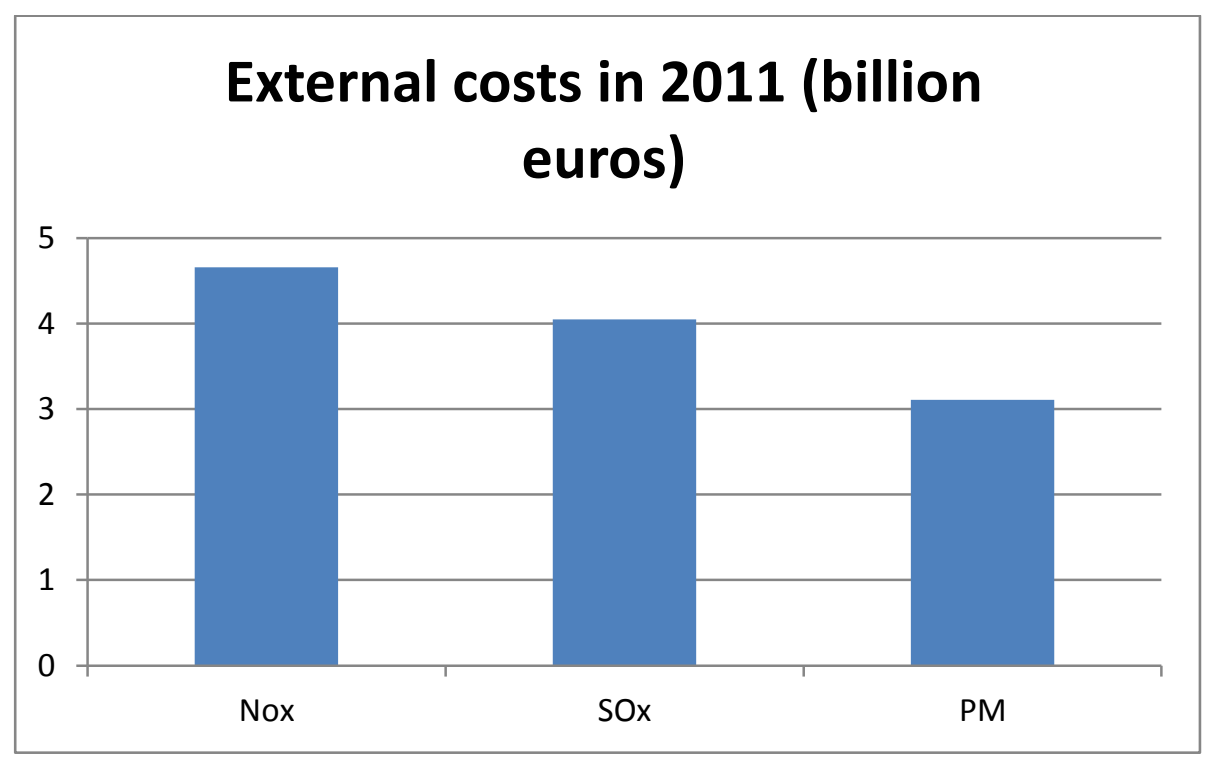

Source: Author's calculations and elaborations, based on data from Lloyds Marine Intelligence Unit

\subsection{Estimated shipping emissions in ports in 2050}

Most shipping emissions in ports will grow fourfold up to 2050. This is the case for $\mathrm{CH}_{4}$ $\mathrm{CO}, \mathrm{CO}_{2}$ and $\mathrm{NO}_{x}$-emissions. This would bring $\mathrm{CO}_{2}$-emissions from ships in ports to approximately 70 million tonnes in 2050 and $\mathrm{NO}_{x}$-emissions up to 1.3 million tonnes. The level of $\mathrm{PM}_{10}$ and $\mathrm{PM}_{2,5}$-emissions from ships in ports remains at the level of 2011 emissions and $\mathrm{SO}_{\mathrm{x}}$ emissions decline slightly compared to the 2011 level (Figure 8). The growth in most shipping emissions is driven by growing demand for certain commodities and goods fuelled by growth of population, economy and trade. The projections are based on the ITF freight model that predicts the flows of 18 different cargo types between 226 places in 84 different countries. These growth rates for cargo types have been translated into growth projections of port calls of the corresponding ship types in each country. In this calculation we assume that ship turnaround times remain at a similar level and that all international obligations that have an impact on ship emissions will be implemented in the timelines currently foreseen, e.g. the reduction of the maximum allowed sulphur content in fuels to $0.5 \%$ by 2020 , and to $0.1 \%$ by 2015 in emission control areas. 
Figure 8. Increase in shipping emissions in ports 2011-2050

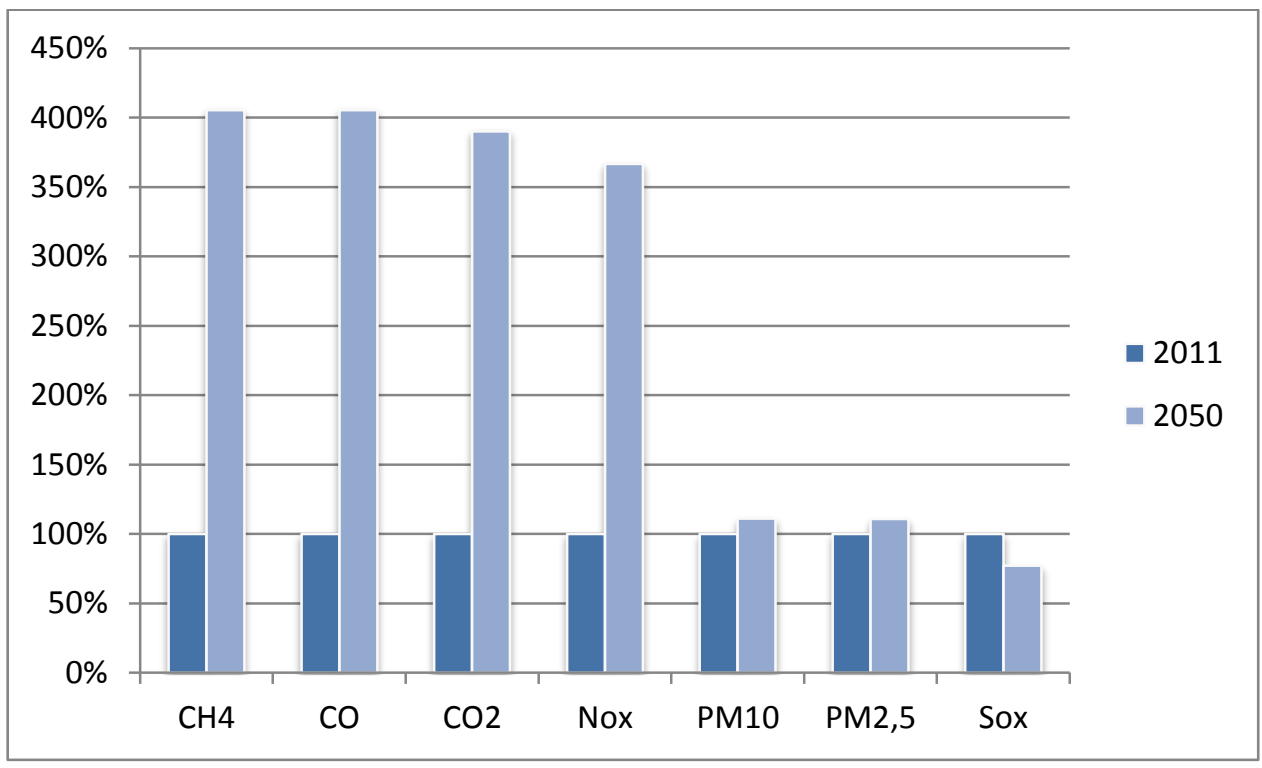

Source: Author's calculations and elaborations, based on data from Lloyds Marine Intelligence Unit

Asia and Africa will be subject the sharpest increases in emissions, due to their projected strong port traffic growth to 2050 and the lack of regional mitigation measures (such as ECAs). Asian port traffic is projected to reach half of the global total in 2050, which corresponds to the share of projected shipping emissions in Asian ports. European and North American ports show relative declines of emissions, due to relatively slower traffic growth and to stricter regulatory measures, such as emission control areas. For example, due to the emission control areas and the $0.1 \%$ maximally allowed sulphur content in these areas from 2015, $\mathrm{SO}_{\mathrm{x}}$-emissions in European and North European ports are projected to be $5 \%$ of the total $\mathrm{SO}_{\mathrm{x}}$-emissions in ports, whereas their total port traffic would account for $24 \%$ in 2050 (Figure 9).

Figure 9. Shares of emissions and port calls, 2011 and 2050

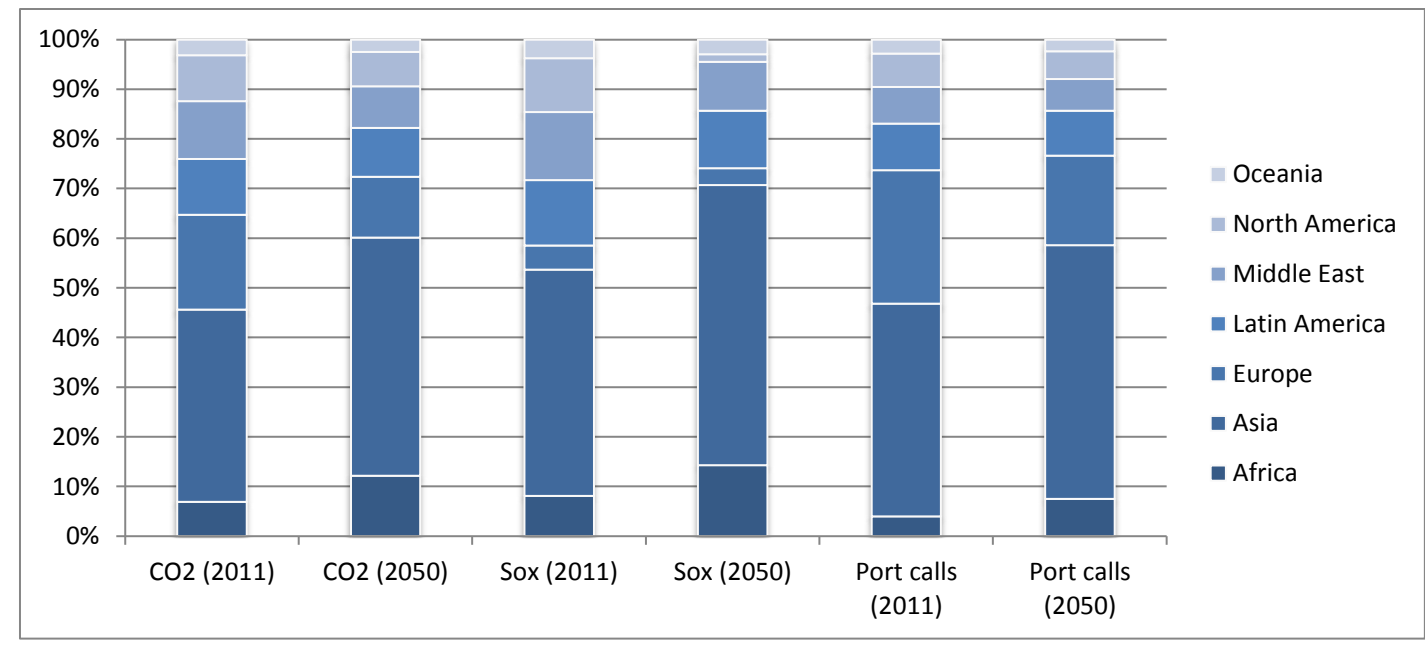

Source: Author's calculations and elaborations, based on data from Lloyds Marine Intelligence Unit 


\section{POLICY IMPLICATIONS}

In order to reduce these projected emissions, strong abatement measures will be needed. These could be classified in four different categories (DNV, 2010):

i) Alternative fuels or power sources. Alternative fuels include gas-fuelled engines (such as LNG and LPG) and biofuels. Alternative energy sources to power ships could be solar power, wind and nuclear energy.

ii) Operational measures. These measures cover operation of the ship itself (hull condition, propeller condition, trim/draft optimisation) and routing measures, such as voyage execution and weather routing (avoiding navigation in areas with bad weather conditions).

iii) Technical measures. These cover the machinery (main and auxiliary engines) and measures under water (propeller and hull).

iv) Structural changes. These changes include port efficiency, vessel speed reduction (through fleet increase) and cold ironing (using shore power while at berth).

These four different categories of abatement measures determine to a large extent the room for policy responses. Significant progress in terms of global policy-making has been made with respect to operational and technical measures. The IMO amended the MARPOL Annex VI in 2011, adding a new chapter on "Regulations on Energy Efficiency for Ships". It includes two measures that came into force in early 2013 and apply to all vessels over 400 GT (gross tonnage): the Energy Efficiency Design Index (EEDI) for all new ship constructions, and the Ship Energy Efficiency Management Plan (SEEMP) for existing ships. The EEDI phases in progressively stringent criteria into the building standards for different types and sizes of ships. Energy efficiency levels are measured in $\mathrm{CO}_{2}$ emissions per capacity mile, and are designed to bear upon all production components of a given ship. The SEEMP constitutes a mechanism for benchmarking and improving operable ships, mainly through the Energy Efficiency Operator Indicator (EEOI) instrument. Under the SEEMP, owners and operators are periodically brought to review and upgrade their energy performance, focusing on such measures as engine tuning and monitoring, propeller upgrades, trim/draft improvement and enhanced hull coating.

An IMO-commissioned study has claimed that, under high uptake scenarios (30\%), the EEDI and SEEMP should reduce global emissions below the status quo scenario by an average of 330 million tonnes (40\%) annually by 2030, and increase savings in the shipping industry by USD 310 billion annually (Lloyd's Register and DNV, 2011). Nevertheless, the model suggests that MARPOL measures will not be sufficient to bring about an overall reduction in emissions relative to 2010 levels. In each of the uptake scenarios tested, projected growth in trade will overwhelm any emissions reductions achieved through the EEDI and SEEMP, even if the upward trend will be reduced compared to status quo scenarios. As becomes clear from our calculation, the projected increase of air emissions from shipping is particularly high for $\mathrm{CO}_{2}, \mathrm{CO}, \mathrm{CH}_{4}$ and $\mathrm{NO}_{\mathrm{x}}$. 
Consensus on global market-based mechanisms - deemed necessary to reduce emissions to levels low enough to impact the pace of climate change - has been elusive within the IMO. Shipping could be included in global emissions trading schemes and climate finance schemes. At least 10 different market-based measures (MBMs) for GHG emissions reductions have been submitted by member-states to the IMO. However, for the moment, opinion has been highly divided within the IMO about the legitimate use of MBMs to bring down GHG emissions from shipping. Part of the difficulty encountered within the IMO discussions has been that any global GHG reduction plan established by the IMO might engage nations who currently have no GHG reduction targets under the Kyoto Protocol to accept these for the fleet of vessels under their registry. This, many nations fear, might establish an unwelcome precedent for the overall climate change negotiations being held under the auspices of the UNFCCC and in which the principle of "common but differentiated responsibilities" has been accepted (Crist, 2009).

Nevertheless, some sort of compromise should be found, possibly by designing a system in which IMO principles can be upheld, while providing some compensatory measures and development support for some of the developing nations that are large flag states.

The levels of $\mathrm{SO}_{x}$ and particulate matter are not expected to increase up to 2050, due to regulations that will come in force in the coming years. These measures should evidently be implemented and the implementation should be controlled, so that the emission reductions will take place. Substantial decreases of $\mathrm{SO}_{x}$ and $\mathrm{PM}$ would be possible by extending the boundaries of existing ECAs and by introducing new ECAs. Extension of boundaries of existing ECAs could be considered in cases where certain ports outside ECAs could attract more traffic because of their cost advantage for shipping lines (e.g. in the case of Liverpool compared to other UK ports). New ECAs have been discussed for the Pearl River Delta (Merk and Li, 2013) and the Mediterranean Sea.

A lot could also be gained by policy initiatives of ports themselves. Various ports have developed infrastructure, regulation and incentives that mitigate shipping emissions in ports. Many of these instruments could be considered the fourth category of abatement measure indicated above: structural measures. An example of infrastructure that reduces ship emissions are shore power facilities that allow ports to shut of their engines when berthing in a port. Especially in Europe and North America, an increasing number of ports provide shore power to ships that come into their quays, following the lead of Gothenburg. Instead of using their diesel-fuelled auxiliary engines, these ships use power generated by the local grid, which significantly diminishes diesel- and other fuel-derived emissions while in port. Shore power not only requires an on-shore power connection, but also ships that are able to connect to this power source. For this reason, shore power is most feasible for point-to-point connections, such as ferries, container lines and Ro/Roships.

Several European ports have begun promoting the use of liquefied natural gas (LNG) as a ship fuel. Bremenports, which is responsible for the management and development of Bremen and Bremerhaven, has decided to actively support the future use of LNG. In addition to the construction of an LNG depot in 2011, one of its main strategies is to use LNG itself, through the creation of ship services powered by LNG in 2012. It is hoped the use of LNG by the service fleet will set a precedent for other users in the port, and Bremenports has a policy of providing technical expertise on these matters to facilitate the popularisation of such technologies. The ports of Rotterdam and Gothenburg already run incentive schemes that subsidise the use of LNG by ships. Both ports are also investing in LNG facilities. Gothenburg and Rotterdam have already begun co-operating on standardisation efforts to ensure that LNG is handled in a uniform manner and to speed up the development and adoption of LNG as a fuel (Merk, 2013). 
Port regulations have so far covered vessel speed reductions in proximity of the port and mandatory fuel switches. Incentives applied by ports include lower tariffs for ships that use cleaner fuels, are more energy efficient or reduce their speed when close to a port. E.g., the Port of Long Beach, through its Vessel Speed Reduction Programme (VSR), rewards ships that voluntarily lower their speeds within the harbour, through reduced docking fees for vessels that remain within a 12-knot speed limit. The goal of the VSR is to reduce $\mathrm{NO}_{x}$ emissions from ocean-going vessel by slowing their speeds as they approach or depart the port, generally at 20 nautical miles $(\mathrm{nm})$ from Point Fermin (OECD, 2011).

Various ports have introduced environmentally differentiated port dues, based on the environmental ship index (ESI). The effect of these incentives is for the moment fairly small, as the number of vessels that qualify for reduced port dues is limited. As the number of ships integrated in the ESI is steadily rising, the prospective benefits will rise, but the rebates have not so far been financed by a rise in dues for the non-ESI vessels, which will have negative consequences for the budgets of the participating ports. So future schemes would arguably not only have to reward clean ships, but also to penalise dirty ships, as is the case in Sweden. This country has applied environmentally differentiated port dues since 1996, following an agreement between the Swedish Maritime Administration, Ports of Sweden and the Swedish Ship-Owners Association to reduce $\mathrm{NO}_{x}$ and $\mathrm{SO}_{2}$ emissions from ships. This agreement has led to environmentally differentiated fairway and port dues.

Voluntary fuel switch programmes are applied in various ports and provide incentives to shipping lines to use low sulphur fuel. These incentives are either in the form of compensations to shipping lines for the additional fuel costs due to their fuel switches, or lower port dues and tariffs. Both the programmes in Seattle and Houston give reimbursements to shipping lines based on the volume of low-sulphur fuel burned during each port call. In contrast, the Green Port Programme in Singapore gives a 15\% reduction of port dues for vessels that switch to clean fuel (or use approved scrubbers or other abatement measures). These programmes usually take the form of collaboration between the port administration and one or more shipping lines. E.g. the programme in Houston is exclusively with the shipping line CMA CGM, whereas the Fair Winds Charter in Hong Kong was with the main 17 shipping lines calling the port. An important port regulation with respect to fuel switching is the EU Sulphur Directive that prescribes that ships at berth in EU ports need to use fuels with a maximum of $0.1 \%$ sulphur content, which is in place since January 2010.

In various cases these instruments are combined or applied subsequently, e.g. when incentive schemes facilitate a transition to stricter regulation (Box 1). Many of the policy choices made will depend on the local situation, but the most convincing examples of policy performance involve a coherent package of inter-related instruments. Mitigating shipping emissions in ports requires the interplay of different levels of intervention, ranging from the local on up. Given the nature of the shipping industry, some environmental impacts of shipping are best tackled at the global level. Self-regulation of ports can work, but in most cases, external pressure is needed. The policy instruments mentioned above would need wider application in order for ship emissions in ports to be reduced. 


\section{Box 1. San Pedro Bay Ports Clean Air Action Plan}

The San Pedro Bay Ports Clean Air Action Plan (CAAP) is a comprehensive strategy to reduce air pollution emissions from port-related cargo movement. The two San Pedro Bay ports, the largest seaport complex in North America, are also the single largest source of pollution in Southern California, according to the South Coast Air Quality Management District (SCAQMD). In 2005, the twin mega-ports of Los Angeles and Long Beach generated approximately $25 \%$ of the diesel pollution in the region (O'Brien, 2004). The CAAP aims to address the problem of the ports' growing operations and their increasing environmental impact. Its goal was to dramatically reduce emissions and associated health risks for the region without upsetting the continuous port development. The plan was first approved in 2006 and updated in 2010. Near-term plans through 2014 and long-term goals include reducing portrelated emissions by $59 \%$ for $\mathrm{NO}_{x}, 93 \%$ for $\mathrm{SO}_{\mathrm{x}}$ and $77 \%$ for DPM by 2023 and meeting standards to lower the residential cancer risk in the port area from diesel particulates. Under the plan, the twin ports have developed annual emission Inventories, which are made public, to track progress in achieving CAAP standards. The CAAP uses a combination of regulations, fees, grants and incentives to the cargo industry to promote cleaner technology and operational systems, such as the Clean Truck Program, the Vessel Speed Reduction Program and the Alternative Maritime Power Program. To support the development and demonstration of clean-air technology, the ports have also jointly created a Technology Advancement Program that has provided more than USD 9 million in funding to the industry since 2007.

The latest analysis in 2011 indicates that the two ports have substantially reduced the key air pollutants from port-related sources since 2005, including a $71 \%$ and a $75 \%$ reduction in airborne diesel particulates, respectively. Several pillar programmes have significantly contributed to reducing air pollution at the two ports, including the Clean Truck Program (CTP) and the Vessel Speed Reduction Program (VSR).

The CAAP marks a milestone for the port industry in mitigating the environmental impact of maritime operations. The plan was a co-operative venture, and the two ports initiated the concept and brought along industry stakeholders and agency leaders (Giuliano and Linder, 2011). The key factor in its success is the co-operation of port users, including terminal operators, truckers and shippers, as well as the support of federal, state and local regulatory bodies and local communities (Mongelluzzo, 2012). The ports were also under considerable social pressure. Community concern over the health risks of port-related diesel emissions had grown after a series of air quality studies was published on the correlation between cancer and respiratory disease rates and proximity to freight-movement corridors. Cargo volumes rose through 2004, in an expansion of capacity at the two ports, and public opposition, including a series of lawsuits, made plans for expansion difficult if not impossible. Political pressure for increased regulatory oversight also prompted the ports to respond to public dissatisfaction over air quality. This ultimately led to the adoption of a comprehensive plan. The CAAP was portrayed as a solution to build the credibility of the ports to obtain agreements on future projects as they engaged all the key stakeholders. One study describes the CAAP as "a response to the loss of social legitimacy and to social and regulatory pressures that were restricting the ability of the ports to expand" (Giuliano and Linder, 2011). The two ports' market influence also played a role in the mitigation efforts, since their gateway location gave them more room to impose fees on the industry and generate the revenue to implement environmental policies.

Source: Merk (2013), The Competitiveness of Global Port-Cities: Synthesis Report, OECD, Paris 
Ship emissions in ports follow a highly skewed distribution pattern, with more than a third of the emissions occurring in only 50 ports. This points to the concentration of air pollution in selected environmental hotspots, but also suggests that policy interventions with respect to environmental externalities, such as on shore power supply, would be most effective if focussed on these places. Although we did not find indications of economies or diseconomies of scale with regards to relative emissions, there were certainly geographical differences. The shipping-related emissions in Asian and European ports are large in absolute terms, but small in relative terms: they represent $70 \%$ of total port calls, but only $51-58 \%$ of shipping-related emissions. The explanation for this is their favourable performance in time efficiency in Asia and Europe: shorter port times mean relatively lower emissions. In contrast, the ports in North America, Africa and Oceania have relatively high emissions. In the case of North American ports this is caused by a much larger vessel capacity calling the port, which might be caused be the relatively underdeveloped short sea shipping market in the US. In the case of African ports, the relatively high emissions are caused by unfavourable performance in time efficiency: vessels have longer port stays than on other continents, so the container ship emissions in port areas are larger. A relatively large literature on port efficiency has generated recommendations on how to improve this. Considering that most of the largest ports in the world are Asian or European ports, that is closer to the efficiency frontier, the opportunities of reducing global shipping emissions in ports by improving port efficiency remains essential, but might actually have relatively limited impact.

\section{REFERENCES}

Abrutyte, E., et al. (2014), "Evaluation of $\mathrm{NO}_{x}$ emission and dispersion from marine ships in Klaipeda sea port", Journal of Environmental Engineering and Landscape Management,

Agrawal, H. et al. (2009), "Primary Particulate Matter from Ocean-Going Engines in the Southern California Air Basin", Environmental Science \& Technology, 43 (14), 53985402

Amato, F., et al. (2009), "Quantifying road dust resuspension in urban environment by Multilinear Engine: A comparison with PMF2", Atmospheric Environment, 43, 27702780

APICE (2013), Reducing atmospheric pollution in the Mediterranean port cities; The results of the APICE project, Financed by ERDF

Berechman, J. and Tseng, P. (2012), "Estimating the environmental costs of port related emissions: The case of Kaohsiung", Transportation Research Part D, 17, 35-38

CARB (2008), "Emissions Estimation Methodology for Ocean-Going Vessels", California Air Resources Board, Planning and Technical Support Division, May 2008

Castells Sanabra, M. et al. (2014), "Manoeuvring and hotelling external costs: enough for alternative energy sources?", Maritime Policy \& Management, 41:1, 42-60 
Civic Exchange (2009), "Green Harbours II: Reducing Marine and Port-related Emissions in the Pearl River Delta Region", Civic Exchange, Hong Kong

Contini, D., et al. (2011), "The direct influence of ship traffic on atmospheric PM2.5, $\mathrm{PM}_{10}$ and PAH in Venice", Journal of Environmental Management, 92, 2119-2129

Corbett, J., et al. (2007), "Mortality from Ship Emissions: A Global Assessment", Environmental Science and Technology, Vol. 41 (24), pp 8512-8518

Crist, P. (2009), "Greenhouse Gas Emissions Reduction Potential from International Shipping", ITF Discussion Paper, No. 2009-11

Cullinane, K., Cullinane, S. (2013), "Atmospheric Emissions from Shipping: The Need for Regulation and Approaches to Compliance", Transport Reviews, 33:4, 377-401

Dalsoren, S. et al. (2008), "Update on emissions and environmental impacts from the international fleet of ships; the contribution from major ship types and ports", Atmospheric Chemistry and Physics Discussions, 8, 18323-18384

De Meyer, P., Maes, F., Volckaert, A. (2008), "Emissions from international shipping in the Belgian part of the North Sea and the Belgian seaports", Atmospheric Environment, 42, 196-206

Deniz, C. and Kilic, A. (2009), "Estimation and Assessment of Shipping Emissions in the Region of Ambarli Port, Turkey", Environmental Progress \& Sustainable Energy, 29:1, 107-115

Donateo, A. et al. (2014), "Contribution of harbour activities and ship traffic to $\mathrm{PM}_{2.5}$, particle number concentrations and PAHs in a port city of the Mediterranean Sea (Italy)", Environ Sci Pollut Res, 21: 9415-9429

DNV (2010), "Pathways to low carbon shipping; Abatement potential towards 2030", Den Norske Veritat (DNV), Oslo, Norway

Entec (2002), "Quantification of emissions from ships associated with ship movements between ports in the European Community, Report for European Commission", Entec UK Limited, Cheshire, England

EPA (2000), "Analysis of commercial marine vessels emissions and fuel consumption data", US Environmental Protection Agency, EPA420-R-00-002

Eyring, V. et al. (2005), "Emissions from international shipping: 1 . The last 50 years", Journal of Geophysical Research, vol. 110, DI17305, doi:10.1029/2004JD005619

Gariazzo, C., et al. (2007), "Application of a Lagrangian particle model to assess the impact of harbour, industrial and urban activities on air quality in the Taranto area, Italy", Atmospheric Environment, 41, 6432-6444

Gibson, M. et al. (2013), "Identifying the sources driving observed $\mathrm{PM}_{2.5}$ temporal variability over Halifax, Nova Scotia, during BORTAS-B", Atmospheric Chemistry and Physics, 13, 7199-7213 
Giuliano, G. and A. Linder (2011), "Motivations for Voluntary Regulation: The Clean Air Action Plan," submitted for presentation at the 2012 TRB Annual Meeting, July, http://docs.trb.org/prp/12-2628.pdf.

Han, S. et al (2011), "Estimation of Air Pollutant Emissions from Port-Related Sources in the Port of Incheon", Journal of Korean Society for Atmospheric Environment, 27:4, 460-471

Healy, R., et al. (2009), "Characterisation of single particles from in-port ship emissions", Atmospheric Environment, 43, 6408-6414

Holland, M. et al. (2005), "Damages per tonne emission of $\mathrm{PM}_{2.5}, \mathrm{NH}_{3}, \mathrm{SO}_{2}, \mathrm{NO}_{\mathrm{x}}$ and VOCs from each EU25 Member State (excluding Cyprus) and surrounding seas", AEA Technology plc, European Commission DG Environment, Brussels

Holland, M., Watkiss, P. (2002), "Benefits Table Database: Estimates of the Marginal External Costs of Air Pollution in Europe". Created for the European Commission, DG Environment, Brussels

Hong, Z. et al. (2013), "The Competitiveness of Global Port-Cities: The case of Shanghai - China", OECD Regional Development Working Papers, 2013/23, OECD Publishing, Paris

Hulskotte, J., Denier van der Gon, H. (2010), "Fuel consumption and associated emissions from seagoing ships at berth derived from an on-board survey", Atmospheric Environment, 44:9, 1229-1236

Human Impact Partners. (2010). "Los Angeles and Long Beach Maritime Port HIA Scope." Prepared for the United States Environmental Protection Agency. Working Draft. May 17, 2010

ICF (2006), "Current methodologies and best practices in preparing port emission inventories", US EPA, Fairfax, Virginia

IMO (2009), "Second IMO GHG Study 2009", International Maritime Organisation, London

IMO (2014), "Third IMO GHG Study 2014", International Maritime Organisation, London

Isakson, J., Persson, T., Selin Lindgren, E. (2001), "Identification and assessment of ship emissions and their effects in the harbour of Göteborg, Sweden", Atmospheric Environment, 35, 3659-3666

Jonsson, A., Westerlund, J., Hallquist, M. (2011), "Size-resolved particle emission factors for individual ships", Geophysical Research Letters, Vol. 38, L13809

Joseph, J., Patil, R., Gupta, S. (2009), "Estimation of air pollutant emission loads from construction and operational activities of a port and harbour in Mumbai, India", Environ Monit Assess, 159, 85-98

Liu, T. et al. (2014), "Sulfur Dioxide Emission Estimates from Merchant Vessels in a Port Area and Related Control Strategies", Aerosol and Air Quality Research, 14, 413421 
Lloyd's Register \& DNV. (2011), Assessment of IMO Mandated Energy Efficiency Measures for International Shipping: Estimated $\mathrm{CO} 2$ emissions reduction from introduction of mandatory technical and operational energy efficiency measures for ships, Report Commissioned by IMO, IMO (London).

Lucialli, P. Ugolini, P., Pollini, E. (2007), "Harbour of Ravenna: The contribution of harbour traffic to air quality", Atmospheric Environment, 41, 6421-6431

Marr, I. et al. (2007), "An air quality survey and emissions inventory at Aberdeen Harbour", Atmospheric Environment, 41, 6421-6431

Matthias, V. et al. (2010), The contribution of ship emissions to air pollution in the North Sea regions, Environmental Pollution, 158, 2241-2250

McArthur, D., Osland, L. (2013), "Ships in a city harbour: An economic valuation of atmospheric emissions", Transportation Research Part D, 21, 47-52

Merk, O. (2013), "The Competitiveness of Global Port-Cities: Synthesis Report", OECD, Paris, France

Merk, O. and Li, J. (2013), "The Competitiveness of Global Port-Cities: the case of Hong Kong, China", OECD Regional Development Working Papers, 2013/16, OECD, Paris, France

Miola, A. and Ciuffo, B. (2011), Estimating air emissions from ships: Meta-analysis of modelling approaches and available data sources, Atmospheric Environment, 45, 2242-2251

Mongelluzzo, B. (2012), "How California's Ports Cleared the Air", The Journal of Commerce, January 232012.

Mueller, D., et al. (2011), "Ships, ports and particulate air pollution - an analysis of recent studies", Journal of Occupational Medicine and Toxicology, 6:31

$\mathrm{Ng}$, S. et al. (2013), "Policy change driven by an AIS-assisted marine emissions inventory in Hong Kong and the Pearl River Delta", Atmospheric Environment, 76, 102-112

O'Brien, T. (2004), "Quality of Life and Port Operations: Challenges, Successes and the Future", White Paper prepared for the Sixth Annual CITT State of the Trade and Transportation Industry Town Hall Meeting, August 30, CITT, Long Beach, California, http://www.metrans.org/outreach/townhalls/citt 6th thm.pdf.

OECD (2011), "Environmental Impacts of International Shipping: the role of ports", OECD Publishing, Paris

Pandolfi, M. et al. (2011), "Source apportionment of $\mathrm{PM}_{10}$ and $\mathrm{PM}_{2.5}$ at multiple sites in the strait of Gibraltar by PMF: impact of shipping emissions", Environ Sci Pollut Res, $18,260-269$

Poplawski, K., et al. (2011), "Impact of cruise ship emissions in Victoria, BC, Canada", Atmospheric Environment, 45, 824-833 
Psaraftis, H., Kontovas, C. (2008), "Ship Emissions Study", Prepared for Hellenic Chamber of Shipping, May 2008, Greece

Sabatino, S. Di, et al. (nd), "Contribution of Emission Sources from Shipping in the Port area of Brindisi, Italy", unpublished paper

Saraçoglu, H., Deniz, C., Kiliç, A. (2013), "An Investigation on the Effects of Ship Sourced Emissions in Izmir Port, Turkey", The Scientific World Journal,

Saxe, H. and Larsen, T. (2004), "Air pollution from ships in three Danish ports", Atmospheric Environment, 38, 4057-4067

Sharma, Dinesh C. 2006. "Ports in a Storm." Environmental Health Perspectives. Environews Focus. Volume 114; Number 4. April 2006.

Shin, K., Cheong, J. (2011), "Estimating Transportation-Related Greenhouse Gas Emissions in the Port of Busan, S. Korea", Asian Journal of Atmospheric Environment, Vol. 5-1, pp. 41-46

Song, S. (2014), "Ship emissions inventory, social cost and eco-efficiency in Shanghai Yangshan port", Atmospheric Environment, 82, 288-297

Song, S., Shon, Z. (2014), "Current and future emission estimates of exhaust gases and particles from shipping at the largest port in Korea", Environ Sci Pollut Res, 21: $6612-6622$

Starcrest Consulting (2004), "Port of Los Angeles baseline air emissions inventory, prepared for the Port of Los Angeles"

Starcrest Consulting (2011), "Port of Los Angeles inventory of air emissions - 2010", Technical Report ADP\#050520-525

Trozzi, C., Vaccaro, R., Nicolo, L. (1995), "Air pollutants emissions estimate from maritime traffic in the Italian harbours of Venice and Piombino", The Science of the Total Environment, 169, 257-263

Tzannatos, E. (2010a), "Ship emissions and their externalities for the port of Piraeus Greece", Atmospheric Environment, 44, 400-407

Tzannatos, E. (2010b), "Ship emissions and their externalities for Greece", Atmospheric Environment, 44, 2194-2202

Tzannatos, E. (2011), "Ship generated exhaust emissions and their externalities for Greece", International Journal Ocean and Climate Systems, 2:1, 65-74

Viana, M. et al. (2009), "Chemical Tracers of Particulate Emissions form Commercial Shipping", Environmental Science \& Technology, 43 (19), 7472-7477

Villalba, G and Gemechu, E. (2011), "Estimating GHG emissions of marine ports - the case of Barcelona", Energy Policy 39, 1363-1368

Yang, D. et al. (2007), "An Emission Inventory of Marine Vessels in Shanghai in 2003", Environmental Science \& Technology, 41 (15), 5183-5190 
Yau, P. et al. (2012), "Estimation of exhaust emission from ocean-going vessels in Hong Kong", Science of the Total Environment, 431, 299-306

Yau, P. et al. (2013), "Contribution of ship emissions to the fine particulate in the community near an international port in Hong Kong", Atmospheric Research, 124, $61-72$ 
